\title{
The Role of Mitochondria in Syncytiotrophoblast Cells: Bioenergetics and Steroidogenesis
}

\author{
Federico Martinez, Rebeca Milan, Oscar Flores-Herrera, \\ Sofia Olvera-Sanchez, Erika Gomez-Chang and Maria Teresa Espinosa-Garcia \\ Universidad Nacional Autónoma de México, Departamento de Bioquímica, \\ Facultad de Medicina, Distrito Federal, \\ Mexico
}

\section{Introduction}

Human placenta maintains pregnancy. The mitochondria of this tissue synthesize pregnenolone (P5) from cholesterol through a transport chain formed by adrenodoxin, adrenodoxin reductase and cytochrome P450scc (CYP11A1; EC 1.14.15.6), which breaks up the lateral chain of cholesterol. P5 is transformed into progesterone (P4) within mitochondria by the $3 \beta-\mathrm{OH}$-steroid-dehydrogenase- $\Delta^{5-6 i s o m e r a s e}$ (3HSD). The particular hormone(s) or substance(s) that modulate P4 synthesis during pregnancy is currently unknown (Strauss et al., 1996; Martinez \& Strauss, 1997); nevertheless, the presence of cAMP analogues stimulated P4 synthesis in trophoblastic cells, suggesting that a hormonal signal or another kind of signal may modulate the concentration of this second messenger into the cells (Ringler et al., 1989; Strauss et al., 1992). Although P4 synthesis was suggested to be the main function of the placenta, the analysis of P450scc cytochrome concentration shows that placental mitochondria have a lower content of P450scc than respiratory chain cytochromes (Table 1), even when it is compared to adrenal gland mitochondria, suggesting that placental mitochondria participate in other functions different to that from steroidogenesis.

\begin{tabular}{|c|c|c|c|c|c|c|c|}
\hline & \multicolumn{3}{|c|}{ Human Placenta } & \multicolumn{4}{|c|}{ Adrenal Glands } \\
\hline Cytochrome & \multicolumn{3}{|c|}{$\begin{array}{c}\mathrm{nmol} / \mathrm{mg} \\
\text { of mitochondrial protein }\end{array}$} & \multicolumn{4}{|c|}{$\begin{array}{c}\mathrm{nmol} / \mathrm{mg} \\
\text { of mitochondrial protein }\end{array}$} \\
\hline$a_{1}+a_{3}$ & 0.140 & 0.10 & - & 0.23 & 0.75 & & \\
\hline$b$ & 0.089 & 0.07 & - & 0.17 & 0.32 & & \\
\hline$c+c_{1}$ & 0.125 & 0.13 & & 0.29 & 0.67 & & \\
\hline P450scc & 0.110 & 0.10 & 0.123 & 1.50 & 1.30 & 0.39 & 1.0 \\
\hline Reference & $\begin{array}{c}\text { Négrié et } \\
\text { al., } 1979\end{array}$ & $\begin{array}{c}\text { Simpson } \\
\text { \& Miller, } \\
1978\end{array}$ & $\begin{array}{c}\text { Meigs \& } \\
\text { Ryan, } 1968\end{array}$ & $\begin{array}{c}\text { Cammer } \\
\& \\
\text { Estabrook, } \\
1967\end{array}$ & $\begin{array}{l}\text { Harding } \\
\text { \& Nelson, } \\
1966\end{array}$ & $\begin{array}{c}\text { I. Hanukoglu } \\
\text { \& Z. } \\
\text { Hanukoglu, } \\
1986\end{array}$ & $\begin{array}{c}\text { Jefcoate } \\
\text { et al., } \\
1973\end{array}$ \\
\hline
\end{tabular}

Table 1. Concentration of cytochromes in human placenta and adrenal gland mitochondria 
It seems that ATP synthesis in placental mitochondria is not related to its consumption at the cytoplasm, but rather it is related to the mitochondrial metabolism and, although seemingly contradictory, this allows pregnancy to reach full-term delivery.

\section{Transport}

\subsection{Transport of carbohydrates, lipids, and amino acids}

The development of both placenta and fetus is metabolically related. The mother supplies the essential nutrients for the fetus and the placenta, and their transport is strictly controlled in the placenta by the expression and the activity of specific transporters in the plasma membrane of syncytiotrophoblast (Angiolini et al., 2006). When the development of the fetus is optimal, some transporters of nutrients and ions are downregulated in the placenta; then a decrease of cellular receptors for specific molecules is observed (Hahn et al., 1999).

The placenta uses mainly glucose for its metabolism and at the same time transports it to the fetus that requires $4-8 \mathrm{mg} / \mathrm{kg} / \mathrm{min}$ of glucose for the oxidative phosphorylation (OXPHOS) process (Aldoreta \& Hay, 1995). Two isoforms of GLUT have been identified: GLUT1 and GLUT3 (Kahn \& Flier, 1990). GLUT 1 is responsible of glucose uptake from the maternal circulation and its activity is independent of insulin. Glucose itself down-regulates the placental GLUT1 providing a fetal protection mechanism when maternal glucose is high (Hahn, 1998). GLUT3 is relevant during implantation and establishment of the placenta, and thereafter GLUT3 is not required; suggesting that GLUT3 has no relevance in glucose uptake after the first trimester (Clarson et al., 1997).

Glucose placental transport is accomplished by facilitated diffusion through GLUT1 transporter, but its expression is not affected by the concentration of extracellular glucose (3.7 $\mathrm{mM}$ o $70 \mathrm{mg} / \mathrm{dl}$ maternal and $3.2 \mathrm{mM}$ o $61 \mathrm{mg} / \mathrm{dl}$ fetal) (Ingermann, 1987). It has been reported that the placenta is in constant hypoxia, for which it has a glycolytic metabolism, where $70 \%$ of total glucose is used to produce ATP through anaerobic glycolysis (Hanguel et al., 1986).

Glycogen is synthesized by the human placenta only as a primary response to maternal hyperglycemia. Although glycogen during pregnancy has been reported (Ville, 1953), the placenta does not synthesize glycogen efficiently (Barash et al., 1991). There are data showing the presence of gluconeogenic enzymes (Matalon \& Michals, 1984), and Prendergast et al. demonstrate that the placenta synthesizes glucose, and evidence of the presence of glucose-6-phosphatase has been published (Matsubara et al., 1999; Prendergast et al., 1999); however, it is unknown whether the glucose synthesis might have any physiologic relevance.

The incubation of trophoblastic cells, perfused explants or placentas, produces lactic acid as a result of anaerobic glycolysis used by the fetus (Battaglia, 1989; Piquard et al., 1990). The radioactivity of glucose labeled with ${ }^{14} \mathrm{C}$ showed the following distribution: lactate $60-69 \%$, glycogen $1.3-4.8 \%$, pentose pathway $5 \%$, fatty acids $0.7-1.4 \%$ and $\mathrm{CO}_{2} 1.6-2.4 \%$ (Desoye \& Shafrir, 1994). Similarly, in slices of human placenta from middle gestation, $73 \%$ of glucose was degraded through glycolysis, $10 \%$ through pentose pathway and the rest through lipids formation and glycogen synthesis. Although pentose pathway has been described in the placenta (Shelley, 1979), reports suggest that it does not make an important contribution to 
glucose metabolism (Moe et al., 1991). The placenta can also use fructose or lactate as energy sources.

\begin{tabular}{|c|c|c|}
\hline Condition & Glucose consumption & Lactate production \\
\hline & \multicolumn{2}{|c|}{ mmol/h/g } \\
\hline $95 \% \mathrm{O}_{2}+5 \% \mathrm{CO}_{2}$ & $6.96 \pm 2.50$ & $21.23 \pm 7.79$ \\
\hline $95 \% \mathrm{~N}_{2}+5 \% \mathrm{CO}_{2}$ & $12.50 \pm 3.36$ & $24.06 \pm 5.24$ \\
\hline
\end{tabular}

Table 2. Glucose consumption and lactate production in human placenta (Modified from Schneider et al., 1988).

The placenta transports $50 \%$ of fatty acids to the fetus during the last trimester of pregnancy; that is the reason why $\beta$-oxidation is not a good candidate for ATP generation. In addition, placental membranes have a lipoprotein lipase which catalyzes the degradation of lipoproteins, mainly VLDL (Coleman, 1986). Fatty acids and glycerol are transported by simple diffusion and, once inside the trophoblast, they are bound to proteins and are transported to the basal stratus to diffuse to the fetus.

The following proteins have been related to the transport of lipids, the plasma membrane fatty acid binding protein (pFABPpm), fatty acid transporter protein (FATP) and the cytoplasmic fatty acid binding protein family (FABP) (Hornstra et al., 1995). pFABPpm makes up about $4 \%$ of cytosolic proteins, it is responsible for the intracellular distribution of fatty acids and to the membrane, and mainly binds essential long chain fatty acids. Also, the transport of essential fatty acids by the placenta is important, since these acids are implicated in cell-cell signaling and contribute to the development of the fetal brain, as well as cardiovascular and lung development (Wollet, 2005; Cunningham et al., 2009).

Cholesterol is the precursor of steroid hormones but it is not synthesized by the human placenta. Trophoblast cells express receptors for lipoproteins like LDL, VLDL, and class A scavenger receptors, as well as for the LDL receptor-related protein (LRP), the apolipoprotein $\mathrm{E}$ (apoE) receptor 2, and the scavenger receptor class B type (SR-BI). The cholesterol required for the synthesis of $\mathrm{P} 4$ is provided by maternal lipoproteins (Strauss et al., 1996; Palinski, 2009) (Fig.1).

Protein synthesis is essential for fetal development; the human placenta has at least three different amino acid transporters (neutral, cationic and anionic) coupled to an ionic energy dependent process. Two cationic amino acid transporter systems called $\mathrm{y}^{+}$(Hoeltzli \& Smith, 1989) and $y^{+} \mathrm{L}$ (Fei et al., 1995) are specific for cationic amino acids and are widely expressed in both maternal and fetal sides. System " $y$ " is $\mathrm{Na}^{+}$-independent (Moe, 1995) and system $y^{+} \mathrm{L}$ has higher affinity for lysine and neutral amino acids. Transport of neutral amino acids involves the transporters $\mathrm{A}, \mathrm{ASC}$ and $\mathrm{L}$. Type $\mathrm{A}$ is a $\mathrm{Na}^{+}$-dependent transporter with affinity for amino acids with short polar or linear side chains. System ASC is a $\mathrm{Na}^{+}-$ dependent transport for serine, cysteine, threonine and glutamine. The system $\mathrm{L}$ is a $\mathrm{Na}^{+}$ independent transporter for large aromatic or non-polar branched side chains of amino acids (Yudilevich \& Sweiry, 1985). 


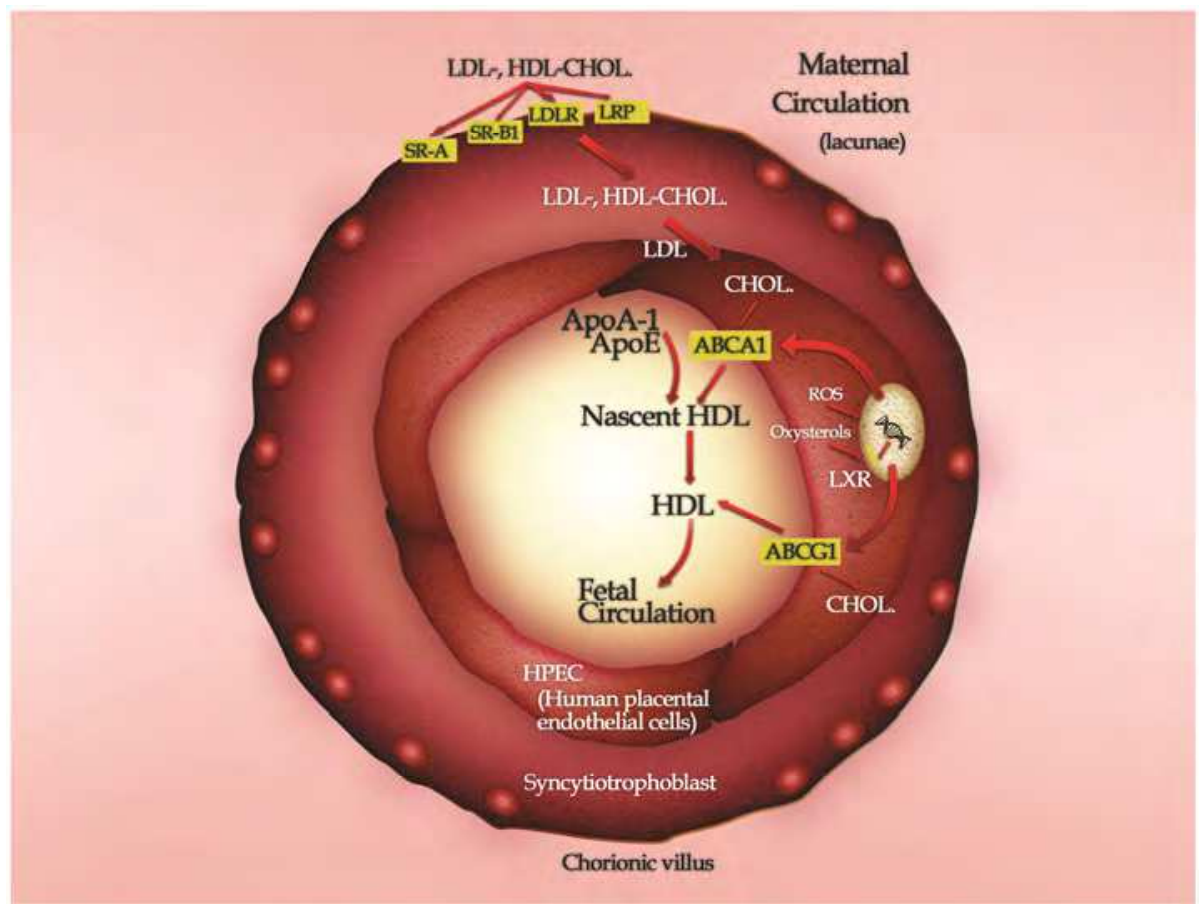

Fig. 1 Maternal-fetal cholesterol transport in the placenta (Modified from Palinski, 2009).

\subsection{Transport of relevant ions}

Ions are needed for fetus growth and metabolism, due to their contribution to cell homeostasis. The ions are not only related to amino acid transport, because ion transporters are necessary for other cellular functions. $\mathrm{Na}^{+}$is transported actively (Stulc et al., 1995). Carter has reported that $30 \%$ of the ATP produced by the placenta is used for the synthesis of proteins and steroids; while $\mathrm{Na}^{+} / \mathrm{K}^{+}$ATPase consumes another 20-30\%, making these processes the most costly and the main consumers of placental energy (Carter, 2000).

Chloride is co-transported with $\mathrm{Na}^{+}$or $\mathrm{K}^{+}$; it is bidirectional and almost symmetrical and apparently associated with the maintenance of cell volume. Calcium is transported to the fetus against a concentration gradient reaching a fetal plasma concentration higher than maternal plasma concentration (Stulc, 1997).

Potassium is taken by the $\mathrm{Na}^{+}-\mathrm{K}^{+}$-ATPase and its efflux through the $\mathrm{K}^{+}$-channel $\left(\mathrm{K}_{\mathrm{ATP}}\right)$; the fetal transport of $\mathrm{K}^{+}$is against a concentration gradient and independent of the maternal potassium status (Stulc, 1997).

The movement of ions in the cell has relevance in the mitochondrial metabolism; the increase of $\mathrm{K}^{+}$in the cytoplasm in adrenal cells stimulates aldosterone synthesis (Spät \& Pitter, 2004). The mechanism involves the release of $\mathrm{Ca}^{2+}$ from its cellular reservoirs modifying the mitochondria metabolism. Human placental mitochondria have a vectorial influx of $\mathrm{Ca}^{2+}$, and changes in its concentration modifies P4 synthesis (García-Pérez et al., 
2002), although this transport can be modified by $\mathrm{K}^{+}$. It has been observed that the increases of $\mathrm{K}^{+}$also modify mitochondrial steroidogenesis (Martinez, 1995). The transport of $\mathrm{K}^{+}$in the mitochondria has not been clarified, but it has been proposed that it could be through the mitoK $_{\text {ATP }}$ channel described by Garlid (Garlid \& Paucek, 2003).

\section{Energetic metabolism}

\subsection{Architecture of the human placental mitochondria}

The size, aspect and organization of mitochondrial membranes vary between species, tissues and physiological conditions. Using isolated mitochondria and cultured cells, Hackenbrock revealed a close coupling between ultrastructure and energetic state (Hackenbrock et al., 1971). In the energized state, when low ADP concentrations are limited for OXPHOS (the socalled respiratory state IV), mitochondria display the common, orthodox conformation: filamentous electron-dense cristae within a matrix of intermediate electron density. When high ADP concentrations accelerate OXPHOS (the respiratory state III), mitochondria adopt the condensed conformation: the matrix is condensed and electron dense, while the intermembrane space and cristae-lumen appears swollen and electron light. Reversible changes between the orthodox and condensed conformation are modulated by metabolites, by drugs that inhibit respiratory complexes or by ionophores that uncouple respiration and phosphorylation (Hackenbrock, 1968, 1971). Decades ago, several authors confirmed that stimulation of respiration induces the condensed conformation, with a characteristic electron-dense matrix in mitochondria (Malka et al., 2005; Rossignol et al., 2004). It is reasonable to assume that mitochondrial ultrastructure, morphology and dynamics are linked and thus, that mitochondrial morphology and dynamics are also modulated by OXPHOS.

Although many types of mitochondrial cristae structure have been described (Munn, 1974), from recent electron microscopic tomography studies, the differences between typical mitochondria are now evident; e.g., liver (Mannella, 1994, 1997), neuronal (Perkins, 1997, 2001a), brown adipose tissue (Perkins et al., 1998), fungus (Nicastro et al., 2000; Perkins et al., 2001b), rods and cones (Perkins, 2003), and those from steroidogenic tissues, e.g., Leydig cells (Prince, 2002). In general, cristae from typical mitochondria are lamellar while in steroidogenic cells are tubular, vesicular, or tubulovesicular (Reichert et al., 2002). It has been suggested that due to this particular morphology of the cristae, mitochondria of Leydig cells should not be able to produce ATP, since the narrow gap between lamellae would not allow the location of the $F_{1}$ subunit of ATP synthase (Prince, 2002); however, a recent publication indicates that mitochondrial membrane potential $(\Delta \psi \mathrm{m})$, mitochondrial ATP synthesis, and mitochondrial respiration are all required to support Leydig cell steroidogenesis (Allen et al., 2006).

In our laboratory, two kinds of mitochondria were isolated from human placenta: non steroidogenic mitochondria with typical cristae from cytotrophoblast, and steroidogenic mitochondria with vesicular cristae from syncytiotrophoblast. In situ, large mitochondria were observed in cytotrophoblast cells, with morphology similar to the typical liver mitochondria, and containing lamellar cristae in an orthodox configuration (Fig. 2). In contrast, the syncytiotrophoblast contains smaller mitochondria with a condensed matrix and cristae composed by vesicular regions connected by narrow tubules. The larger cytotrophoblast mitochondria have a round shape, whereas syncytiotrophoblast 
mitochondria display an irregular shape with protuberances of the outer and inner membranes (De Los Rios Castillo et al., 2011).
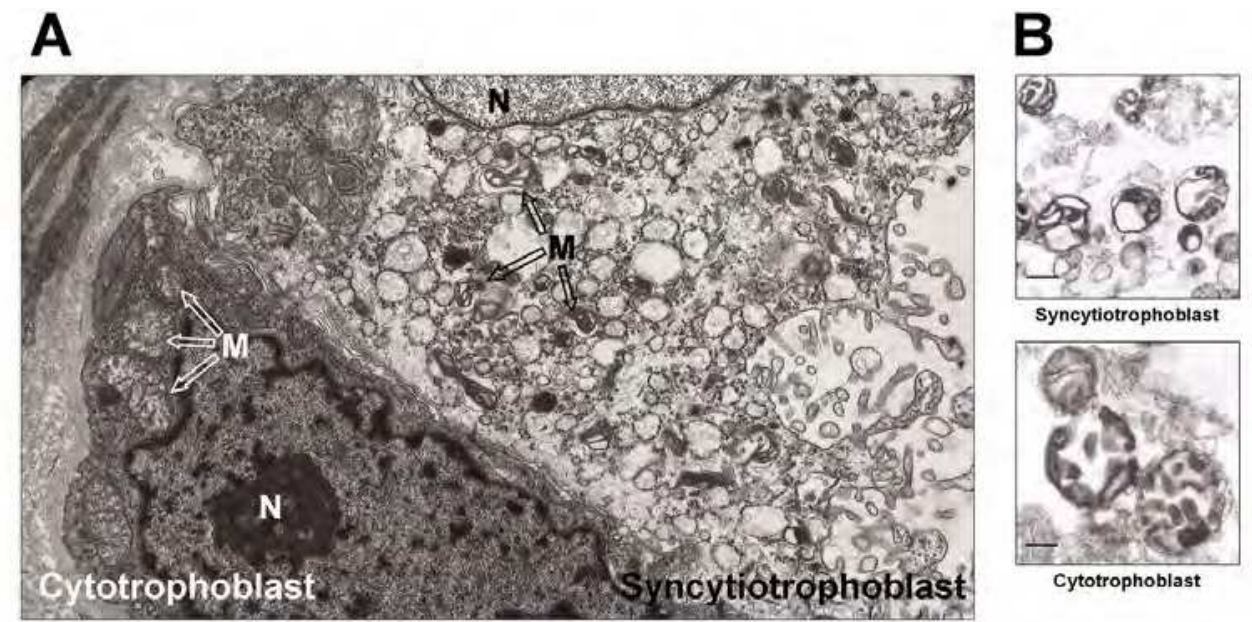

Fig. 2. Ultrastructure of human syncytiotrophoblast and cytotrophoblast cells. (A) Electron micrograph of term placenta villus showing syncytiotrophoblast and underlying cytotrophoblast. N, nucleus; $\mathrm{M}$, mitochondria. 10,000 X. (B) Isolated mitochondria from human cytotrophoblast and syncytiotrophoblast. Scale bar, $200 \mathrm{~nm}$ (Modified from De Los Rios Castillo et al., 2011)

Isolated cytotrophoblast and syncytiotrophoblast mitochondria showed values for respiratory control higher than those previously reported for this tissue (Olivera \& Meigs, 1975 ) and the oxygen uptake was coupled to ATP synthesis, reaching $151 \pm 16$ and $153 \pm 13$ $\mathrm{nmol} \mathrm{ATP} / \mathrm{mg} / \mathrm{min}$, respectively (De Los Rios Castillo et al., 2011). These observations demonstrate the presence of functional mitochondria in both cell types, retaining the ability to increase the consumption of oxygen and the synthesis of ATP upon the addition of ADP.

\subsection{Energetic pathways}

The metabolism of mitochondria involves two major pathways: energy production and P4 synthesis, and several evidences show that both are closely related, as suggested by the similar content of cytochromes from the electron transport chain cytochrome P450scc, suggesting the alternating activity of both pathways, which can generate ATP for cell function and for $\mathrm{P} 4$ synthesis to maintain pregnancy. A mechanism to regulate the functioning of both pathways could be the presence of alternative enzymes, e.g. an NADPdependent isocitrate dehydrogenase is associated to the inner mitochondrial membrane; isocitrate, the substrate for this enzyme supports progesterone synthesis, while succinate promotes the synthesis of ATP.

It has been described that ATP-diphosphohydrolase and ADPase enzymes are tightly bound to mitochondrial membranes and their activities are involved in steroidogenesis. Particularly, the activity of ATP-diphosphohydrolase was described as supporting P4 synthesis, probably providing the energy requirement for cholesterol transport between the mitochondrial 
membranes, similar to the activity of mitochondrial GDPase reported in adrenal gland (Fig. 3) Additionally, these enzymes could participate in the transformation of ATP to adenosine, which can be released into the blood vessels to promote oxygenation of the placenta.

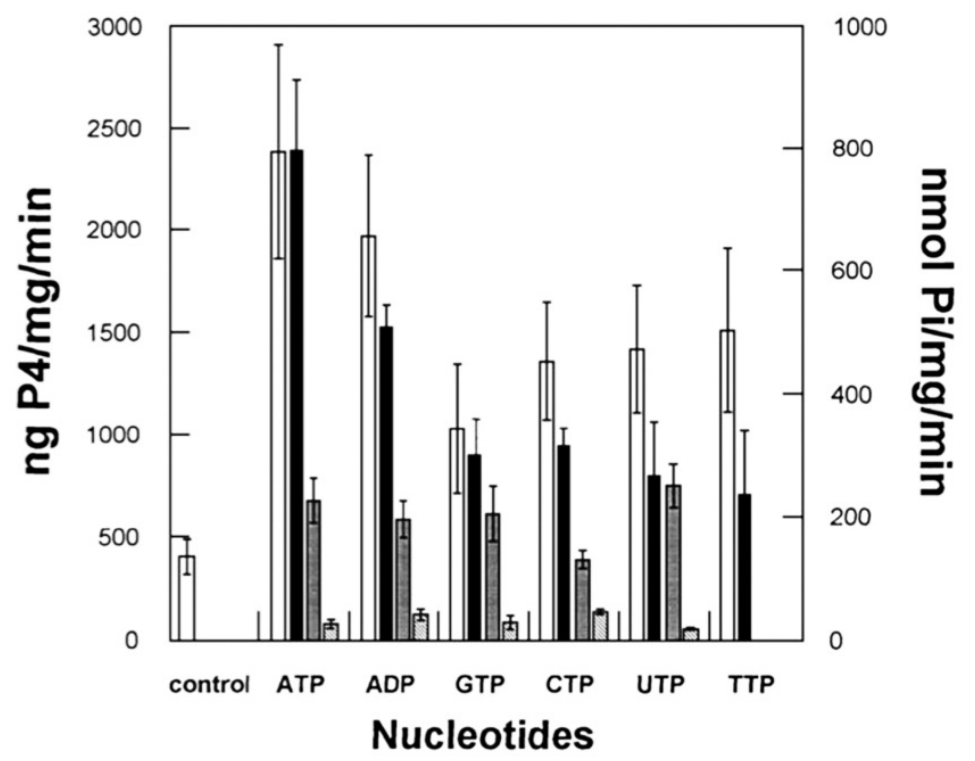

Fig. 3. Effect of several nucleotides on progesterone synthesis and their hydrolysis by human placental apyrase. Mitochondria were incubated in progesterone synthesis medium with or without $1 \mathrm{mM}$ 5'p-fluorsulfonyl benzoyl adenosine (FSBA). Nucleotide hydrolysis was also performed in progesterone synthesis medium. Progesterone synthesis ( $\square$ );

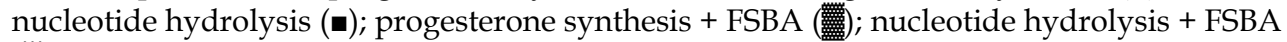
() (Modified from Flores-Herrera et al., 2002).

The concentration of adenine nucleotides is another way to analyze the pathways that produce energy in the form of ATP. The total amount of nucleotides at the time of expelling is 0.766 a $0.816 \mathrm{mmol} / \mathrm{g}$ wet weight, ATP 0.49 , ADP 0.23, and AMP $0.12 \mathrm{nmol} / \mathrm{g}$ wet weight (Young \& Schneider, 1984). In mitochondria isolated from full-term human placenta the concentrations of nucleotides are 1.245 .78 y $1.09 \mathrm{nmol}$ of ATP, ADP, and AMP/mg of protein, respectively (Martinez et al., 1987). These data suggest that in spite of the anoxia produced by labor, the placenta synthesizes mainly ATP, whereas glycogen levels do not vary significantly until 60 minutes after labor (Bloxam \& Bobinski, 1984). The fact that mitochondria synthesize ATP does not imply that they supply the trophoblast with ATP for its cellular functioning in an important amount.

\subsection{The relevance of nucleotide hydrolysis}

With regard to their steroidogenic role, syncytiotrophoblast mitochondria synthesize P4 (35.7 $\pm 0.9 \mathrm{ng} \mathrm{P} 4 / \mathrm{mg} / \mathrm{min}$ ) due to the presence of 3HSD in their inner membrane (Cherradi et al., 1994; Martinez et al., 1997; Brand et al., 1998). Their steroidogenic activity was ten times higher than cytotrophoblast mitochondria $(3.6 \pm 1.34 \mathrm{ng} \mathrm{P} 4 / \mathrm{mg} / \mathrm{min})$. In both cases, 
22(R)-hydroxycholesterol, a soluble substrate used to assess maximal steroidogenesis (Tuckey, 1992) increased steroidogenic activity to $92.2 \pm 3.4$ and $10.1 \pm 3.95 \mathrm{ng} \mathrm{P} 4 / \mathrm{mg} / \mathrm{h}$ in syncytiotrophoblast and cytotrophoblast mitochondria, respectively (De Los Rios Castillo et al., 2011). Additionally we demonstrated that ATP is essential for progesterone synthesis (Flores-Herrera et al., 2002). These results agree with the specialized role of each placental cell (Martinez et al., 1997) and demonstrate that isolated mitochondria from syncytiotrophoblast are intact and retain their physiological function.

Nevertheless, human syncytiotrophoblast mitochondria have bioenergetics and steroidogenic functions, which raise an interesting question: why do they have an irregular shape with tubular, vesicular, or tubulovesicular cristae? At present, there is interest concerning proteins that govern mitochondrial ultrastructure, but few of such proteins have been identified (Pellegrini \& Scorrano, 2007). It has been speculated that the dimer of $\mathrm{F}_{0} \mathrm{~F}_{1}$-ATP synthase (complex V for oxidative phosphorylation of ATP) may play a major role in determining cristae formation (Paumard et al., 2002; Minauro-Sanmiguel et al., 2005; Dudkina et al., 2005; Strauss et al., 2008). Dimerization of $\mathrm{F}_{0} \mathrm{~F}_{1}$-ATP synthase in the mitochondrial inner membrane has been described in yeast (Arnold et al., 1998) and bovine mitochondria (Schägger \& Pfeiffer, 2000). A critical role in the stability of the mammalian dimeric complex $\mathrm{V}$ has been proposed for the inhibitory $\mathrm{F}_{1}$ moiety protein $\left(\mathrm{IF}_{1}\right)$ (García et al., 2006). $\mathrm{IF}_{1}$ is known to dimerize in solution (Gordon-Smith et al., 2001), and this dimer has been recently shown to interact with two molecules of soluble $\mathrm{F}_{1}$ simultaneously (Cabezón et al., 2000; Dominguez-Ramirez et al., 2001). If the same interaction occurs in the membrane, it might be responsible for the dimerization of the $\mathrm{F}_{0} \mathrm{~F}_{1}-\mathrm{ATP}$ synthase complex, and in mammalian cells, changes in $\mathrm{IF}_{1}$ concentration affect the degree of $\mathrm{F}_{0} \mathrm{~F}_{1}$-ATP synthase dimerization, which in turn could alter the formation of cristae (García et al., 2006). In this sense, the density of mitochondrial cristae in HeLa cells is increased by $\mathrm{IF}_{1}$ overexpression and decreased by $\mathrm{IF}_{1}$ suppression (Campanella et al., 2008); interestingly, $\mathrm{IF}_{1}$ overexpression increases both the formation of dimeric $\mathrm{F}_{0} \mathrm{~F}_{1}$-ATP synthase and $\mathrm{F}_{0} \mathrm{~F}_{1}$-ATP synthase activity (Campanella et al., 2008).

The analysis of the electron transport chain and oxidative phosphorylation complexes from human syncytiotrophoblast and cytotrophoblast mitochondria allow us to demonstrate that the dimeric form of the $\mathrm{F}_{0} \mathrm{~F}_{1}$-ATP synthase (complex $\mathrm{V}$ ) is involved in the cristae architecture in trophoblast cells (De Los Rios Castillo et al., 2011). In this sense, we found that the dimer of mitochondrial $\mathrm{F}_{0} \mathrm{~F}_{1}-\mathrm{ATP}$ synthase is scarce in syncytiotrophoblast associated to a low $\mathrm{IF}_{1}$ concentration. Due to the fact that human placenta cells are ontogenetically related, i.e. cytotrophoblast cells differentiate into syncytiotrophoblast cells, the amounts of $\mathrm{IF}_{1}$ found in the steroidogenic cells could be the result of cell differentiation and have a significant effect on their mitochondrial architecture (tubulovesicular cristae) and physiology (P4 synthesis). The amount of $\mathrm{IF}_{1}$ and $\mathrm{F}_{0} \mathrm{~F}_{1}$-ATP synthase dimer present in these mitochondria is probably related to its physiological functions.

But, why do syncytiotrophoblast cells have mitochondria with atypical cristae morphology? Since the human placenta does not express StAR (Tuckey, 2005) and TSPO (MaldonadoMercado et al., 2008), two proteins involved in mitochondrial cholesterol flow, it has been suggested that the reduction in the size of syncytiotrophoblast mitochondria and the change in the structure of cristae may improve the steroidogenic activity of syncytiotrophoblast cells (Martinez et al., 1997). In this sense, the translocation of cholesterol to P450scc has been 
well known to be the rate-limiting step in steroidogenesis; thus, a greater surface could enhance the movement of cholesterol to the inner membrane where P450scc is located. It is tempting to speculate that the non-ortodox cristae structure in mitochondria from steroidogenic tissue allows cholesterol to flow from the outer to the inner mitochondrial membranes and improves hormone production.

\subsection{Mitochondrial accessory proteins involved in progesterone synthesis}

For P4 synthesis by human syncytiotrophoblast mitochondria, the cristae architecture could not be considered as the only and most important issue; we have identified a set of different proteins involved in hormone production as a heat shock protein-60 kDa (HSP60), associated to the increases of progesterone synthesis through its association with the MLN64-like protein (Olvera-Sanchez et al., 2011); an ADPase, and an ATP-diphosphohydrolase associated to mitochondrial membranes (Uribe et al., 1999; Flores-Herrera et al., 1999).

ATP-diphosphohydrolase is anchored to mitochondrial membranes whit its nucleotidehydrolyzing activity oriented to the intermembrane space. The kinetic characterization of its activity in a detergent solubilized fraction revealed that it can use ATP, ADP, GTP, GDP, UTP, UDP, CTP, CDP, TTP and TDP in a cation $\left(\mathrm{Mg}^{+2}, \mathrm{Ca}^{+2}\right.$, and $\left.\mathrm{Zn}^{+2}\right)$ dependent fashion as substrates (Flores-Herrera et al., 1999) (Fig. 4). ATP hydrolysis by this ATPdiphosphohydrolase can stimulate oxygen uptake in intact mitochondria from syncytiotrophoblast coupling with ATP synthesis (Martinez et al., 1993). Since one main function of mitochondria is the synthesis of ATP through the $\mathrm{F}_{0} \mathrm{~F}_{1}$-ATPase activity, the presence of external mitochondria ATP-diphosphohydrolase and an ADPase in the human

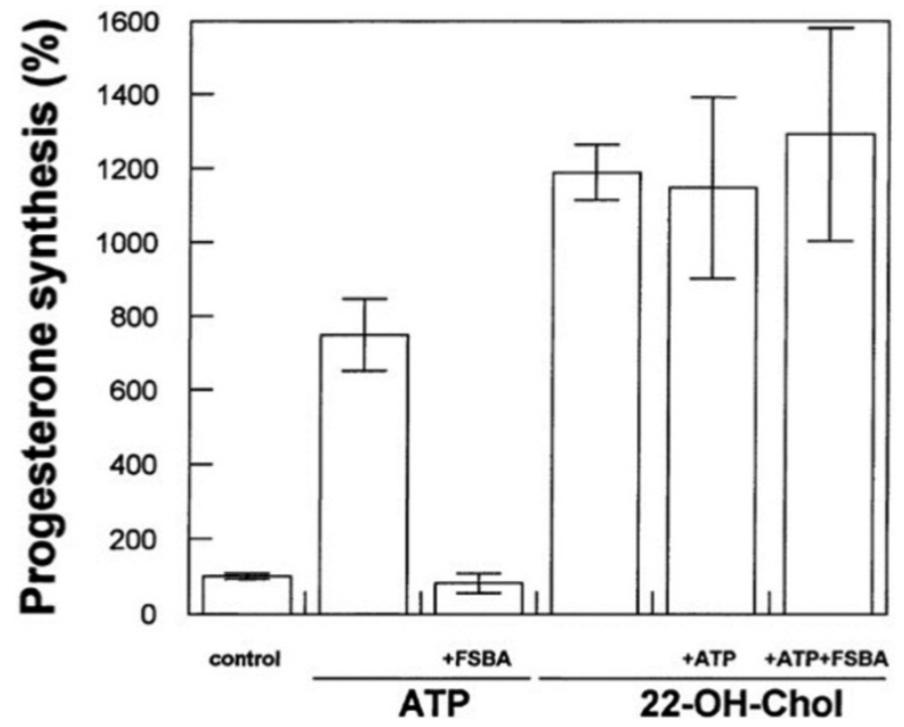

Fig. 4. Effect of 22(R)-hydroxycholesterol (22-OH-Chol) on progesterone synthesis.

Mitochondria were incubated in progesterone synthesis medium with or without $1 \mathrm{mM}$ FSBA. Where indicated, $1 \mathrm{mM}$ ATP or $15 \mu \mathrm{M} 22-\mathrm{OH}-\mathrm{Chol}$ was added. $100 \%$ progesterone synthesis $=142 \mathrm{ng}$ progesterone $/ \mathrm{mg} / \mathrm{min}$ (Modified from Flores-Herrera et al., 2002). 
placental mitochondria could produce a futile cycle due to the combination of the $\mathrm{F}_{0} \mathrm{~F}_{1}$ ATPase and ATP-diphosphohydrolase activities, being lethal for trophoblast cells. However, the futile cycle is not observed, because the addition of ATP (or ADP) to isolated mitochondria induces oxygen consumption without uncoupling the respiration, suggesting the presence of mechanisms that regulate the activity of ATP-diphosphohydrolase in a way that trophoblast cells remain alive (Martinez et al., 1993). Indeed, ATP-diphosphohydrolase activity and its substrate specificity seem to be regulated by the proton electrochemical potential $\left(\Delta \mu_{\mathrm{H}^{+}}\right)$, i.e. if mitochondrial inner membrane is energized, ATP-diphosphohydrolase selectively hydrolyzes ATP, while dissipation of $\Delta \mu_{\mathrm{H}^{+}}$by CCCP produces a loss of substrate specificity, and is able to hydrolyze ATP and GTP equally (O. Flores-Herrera, et al., manuscript in preparation).

With respect to ATP-diphosphohydrolase role in syncytiotrophoblast mitochondria steroidogenesis, its activity in presence of ATP is involved in cholesterol transport between mitochondrial membranes (Flores-Herrera et al., 1999; Flores-Herrera et al., 2002). In addition, other nucleotide hydrolase activities have been determined in mitochondria from other steroidogenic tissues; in particular, in adrenal mitochondria GTP enhances steroidogenesis, a process modulated by a GTPase (X. Xu \& T. Xu, 1989); however, no conclusion can be drawn yet in this steroidogenic tissue. However, syncytiotrophoblast mitochondria hydrolyze several nucleosides tri- and di-phosphatides increasing P4 synthesis, which is sensitive to ATPdiphosphohydrolase inhibition by FSBA, a non-hydrolysable ATP analog (Flores-Herrera et al., 2002) (Fig. 4). Finally, although the mechanisms of regulation of this enzyme have to be elucidated, we conclude that ATP-diphosphohydrolase is anchored to syncytiotrophoblast mitochondrial membranes, which nucleotide hydrolysis activity is involved in cholesterol transport between mitochondrial membranes and in oxygen uptake by mitochondrial electron transport chain (Flores-Herrera et al., 2002).

\section{Signaling pathway in placental steroidogenesis}

\subsection{The role of mitochondria in the phosphorylation cell signaling}

Progesterone synthesis by human placenta is essential for the maintenance of pregnancy. In the human being, P4 is produced in the corpus luteum cells during the secretory phase of the menstrual cycle; whereas in the early stages of pregnancy its production continues due to the stimulus of the Chorionic Gonadotropin hormone (hCG); however, between the 6th and 8th week of gestation, the corpus luteum decreases its production of P4, which is now synthesized by the trophoblastic cells of the placenta (Tuckey, 2005).

Unlike the other steroidogenic tissues, placental steroidogenesis is chronically regulated. Both regulation systems are under the control of diverse factors or hormones that activate signal transduction pathways in different forms, allowing either short-term or long-term regulation. In general, the chronic response is started within hours after the initiating stimulus and involves the activation of certain signaling pathways, among them the cAMPdependent protein kinase (PKA) cascade is the most important.

The effect mediated by PKA/cAMP in long-term and short-term regulation of steroidogenesis is the main pathway stimulated by trophic hormones which acts through $G$ protein-coupled receptors, which in turn activates the enzyme adenylate cyclase, which increases the content of cAMP. cAMP has pleiotropic effects such as the activation of PKA, 
which phosphorylates proteins and transcription factors such as the steroidogenic factor (SF-1) and the protein cAMP response element binding (CREB), the latter being the main mediator of positive changes in gene expression (Sands, 2008); for example, the activation of StAR gene (Stocco et al., 2005) or even its phosphorylation (Fig. 5).

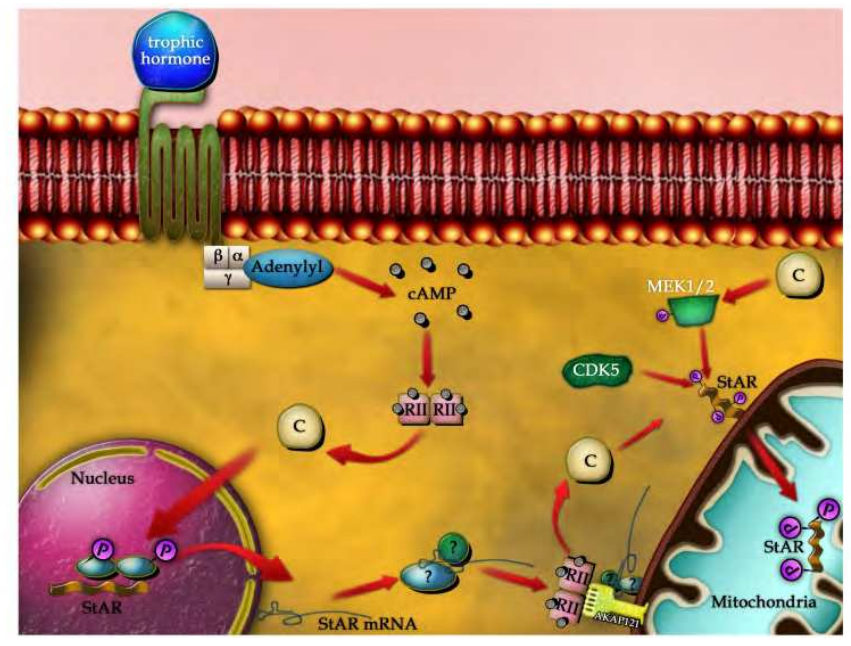

Fig. 5. The model illustrates the activation of the transduction pathway mediated by PKA/cAMP in the postranscriptional and postranslational regulation StAR protein (Modified from Manna, 2009).

Although other PKA-dependent and -independent signaling pathways have been reported, the responses generated are generally less potent than those mediated by PKA/cAMP (Manna et al., 2006).

During pregnancy, the production of $\mathrm{P} 4$ gradually increases with no substantial variations observed (Tuckey, 2005). It has been reported that a plasmatic decrease of P4 is associated with a higher probability of abortion (Duan et al., 2010).

The addition of 8Br-cAMP or dibutyryl-cAMP to cultured trophoblast cells stimulated the $\mathrm{P} 4$ synthesis by increasing the transcription and translation of P450scc and adrenodoxin. Nevertheless, independent of the factors involved modulating the intracellular concentration of cAMP, the likely participation of different hormones and the trophic factors and cytokines that could have endocrine, paracrine, autocrine or intracrine effect in the regulation of steroidogenesis through the signaling pathway mediated by PKA is still unknown; since, as it has been said, there are other pathways that can participate in the regulation of P4 synthesis (Manna et al., 2006; Stocco et al., 2005) (Fig. 6).

In trophoblast choriocarcinoma-derived cells of human placenta (BeWo) the addition of hCG increased P4 synthesis through PKA. Other factors also increased in a variable way the production of $\mathrm{P} 4$; nevertheless, it has been suggested that its main effect would be predominantly as a regulator and just in a few cases as a stimulant of steroidogenesis, although through the activation of cAMP-dependent pathways and PKA activation (Manna et al., 2006). 


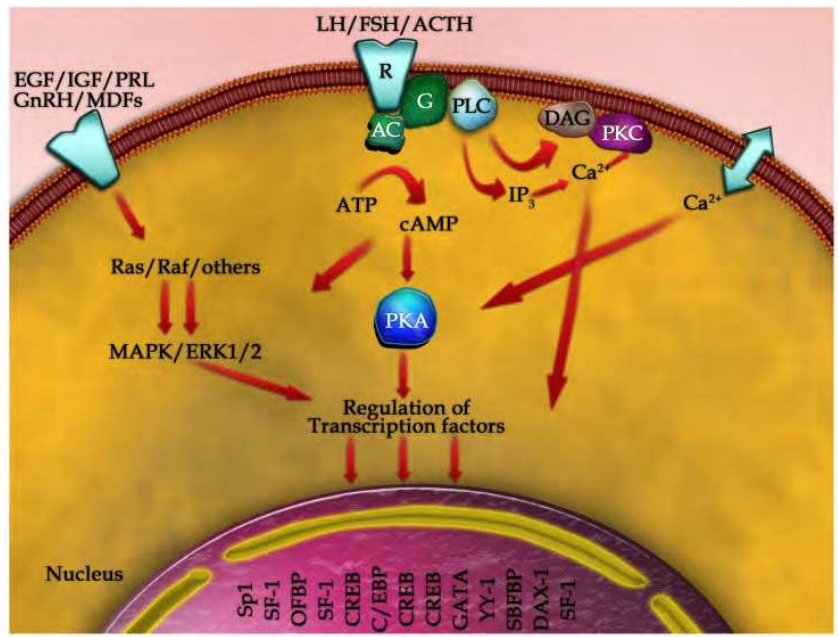

Fig. 6. Model proposed to illustrate the cAMP-dependent and -independent pathways in the regulation of StAR expression and steroidogenesis in adrenal gland and gonads (Modified from Manna, 2009).

Although the signaling pathways associated with P4 synthesis in human placenta are unknown, one of the best studied mechanism is the one mediated by PKA activation. Unlike gonads, adrenal cortex, and the corpus luteum, P4 synthesis by placental cells in the presence of cAMP soluble derivatives produce no acute response, not even in cells obtained from first-trimester placentas (Zosmer et al., 1997).

Previous data confirm that trophoblast cells have the machinery to produce cAMP, which may increase its concentration in cytoplasm through the stimulation of $\beta_{2}$ adrenergic receptors in full-term placentas (Kasugai et al., 1987). Interestingly, in first-trimester placentas, norepinephrine increased the content of cAMP mediated by $a_{1}$-adrenergic receptors (Shi \& Zhuang, 1993). There is also evidence of the potential effect of other hormones that may stimulate placental P4 synthesis through cAMP-dependent pathways, just like it happens in the case of estrogens (Pepe \& Albretch, 1999), insulin (Lavy et al., 1987), insulin-like growth factor 1 (Nestler, 1987) and epidermal growth factor (Ritvos, 1988). The results suggest the possibility of different stimuli for specific effectors according to the gestational age.

The function of PKA in cells is vital, since its activity is aimed at specific functions, which include the differential expression of regulatory and catalytic subunits in different tissues. Thus, anchor proteins (AKAP's, A-kinase anchor proteins) in certain cellular locations place PKA close to its substrates, making its activity more efficient (Fig. 7). For instance, in Leydig tumoral cells from mice the association of AKAP 121 with the regulatory subunit a of PKA II in mitochondria in response to cAMP was observed, which was interpreted as a powering effect of steroidogenesis on directing the synthesis and activation of StAR to the mitochondrion in response to cAMP (Dyson et al., 2008).

In a similar way, mitochondria isolated from human placenta show the interaction of PKA, AKAP-121, and PTPD1 (Gómez-Concha et al., 2011) (Fig. 8). In addition, it was seen that in the presence of radioactive ATP several proteins were phosphorylated in less than 5 min on 


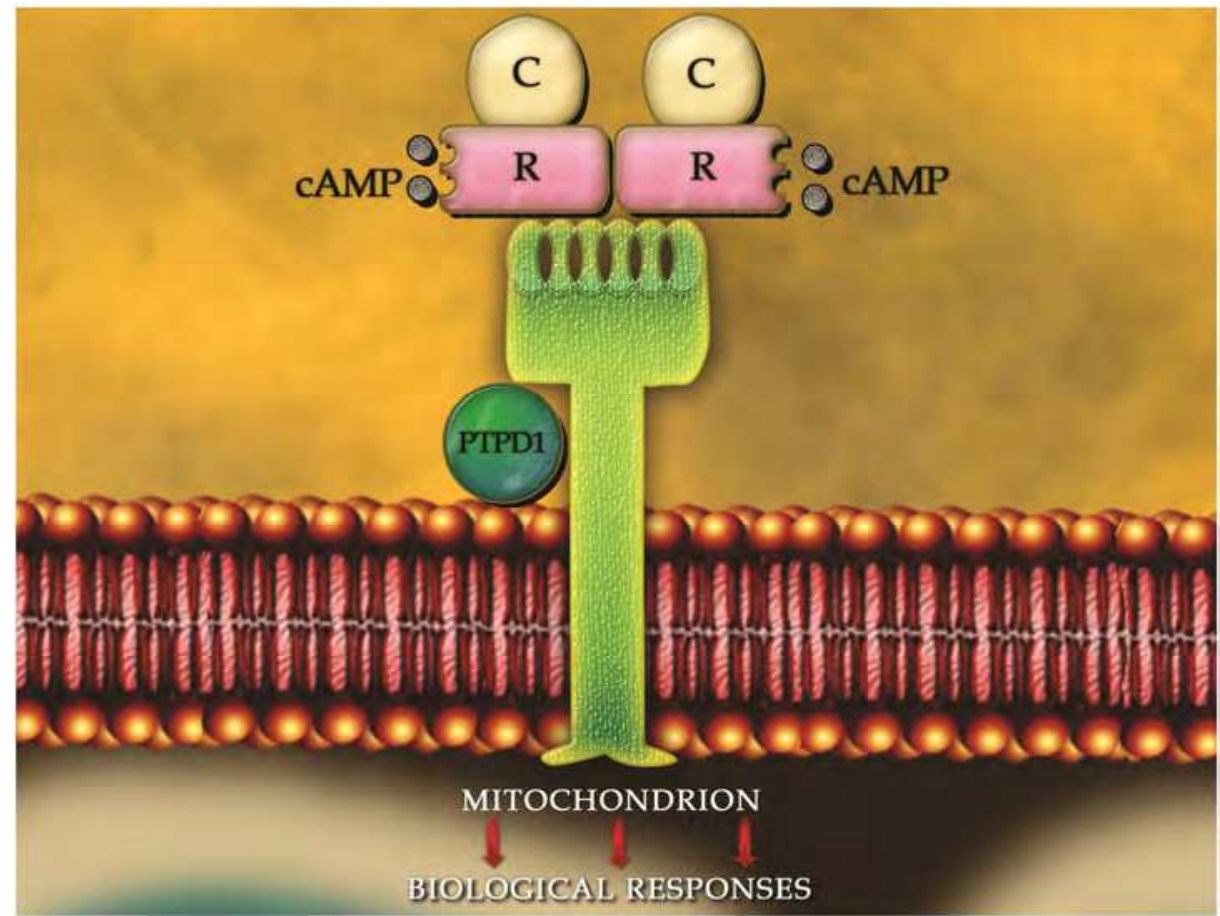

Fig. 7. A signaling complex made up by AKAP 121, which anchors PKA close to the mitochondrion, thus facilitating the phosphorylation of mitochondrial proteins (Modified from Feliciello, 2005).
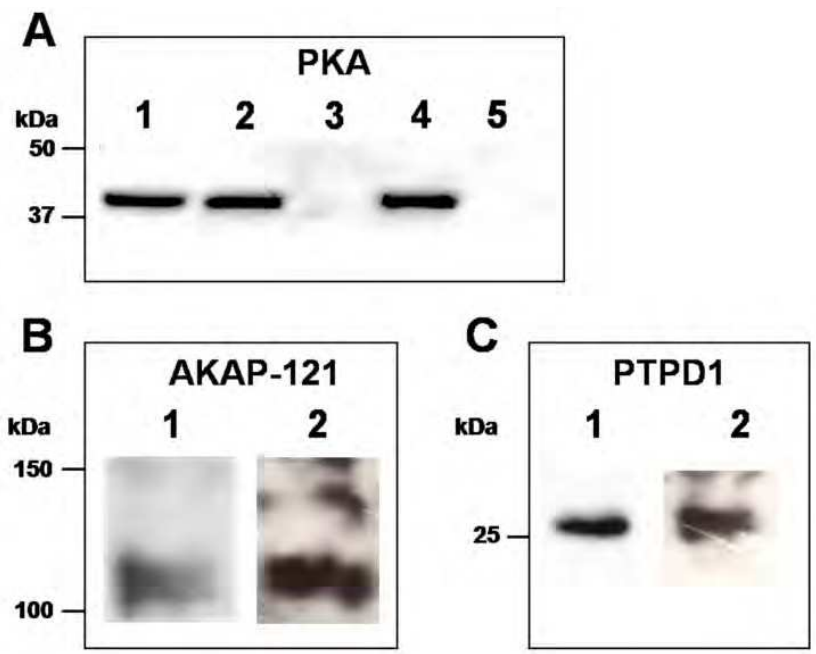

Fig. 8. Immunodetection of PKA (A), AKAP-121 (B) and PTPD1 (C) (see Material and Methods from Gómez Concha, 2011.) 
serine and threonine, and to a lesser degree on tyrosine, suggesting the potential activity of kinases. Likewise, the importance of cAMP-PKA pathway in BeWo cells and in mitochondria isolated from human placenta was shown using H89, an inhibitor of PKA activity (Maldonado-Mercado et al., 2008). In mitochondria isolated from syncytiotrophoblast, steroidogenesis was inhibited $50 \%$ with $100 \mu \mathrm{M}$ of H89, whereas in BeWo cells with concentrations of 10 and $20 \mu \mathrm{M}$, an inhibition of steroidogenesis of $70 \%$ and $90 \%$ was found, respectively. The addition of 22(R)-hydroxycholesterol to the isolated mitochondria previously inhibited with H89, reestablishes P4 synthesis, thus confirming that the activities of P450scc and 3HSD are not affected by H89.

The results show that to the maximal concentration of H89 inhibited the synthesis of P4 in $99 \%$, but only $50 \%$ of protein phosphorylation, which suggests that there are other kinase activities in mitochondria isolated from the human placenta, suggesting the pathway mediated by PKA could be associated to another pathways that ensures the production of $\mathrm{P} 4$; then it is relevant to determine the kinases that participate and their associations with the steroidogenesis by the human placenta as it was proposed (Maldonado-Mercado et al., 2008; Gómez -Concha et al., 2011) (Fig. 9).
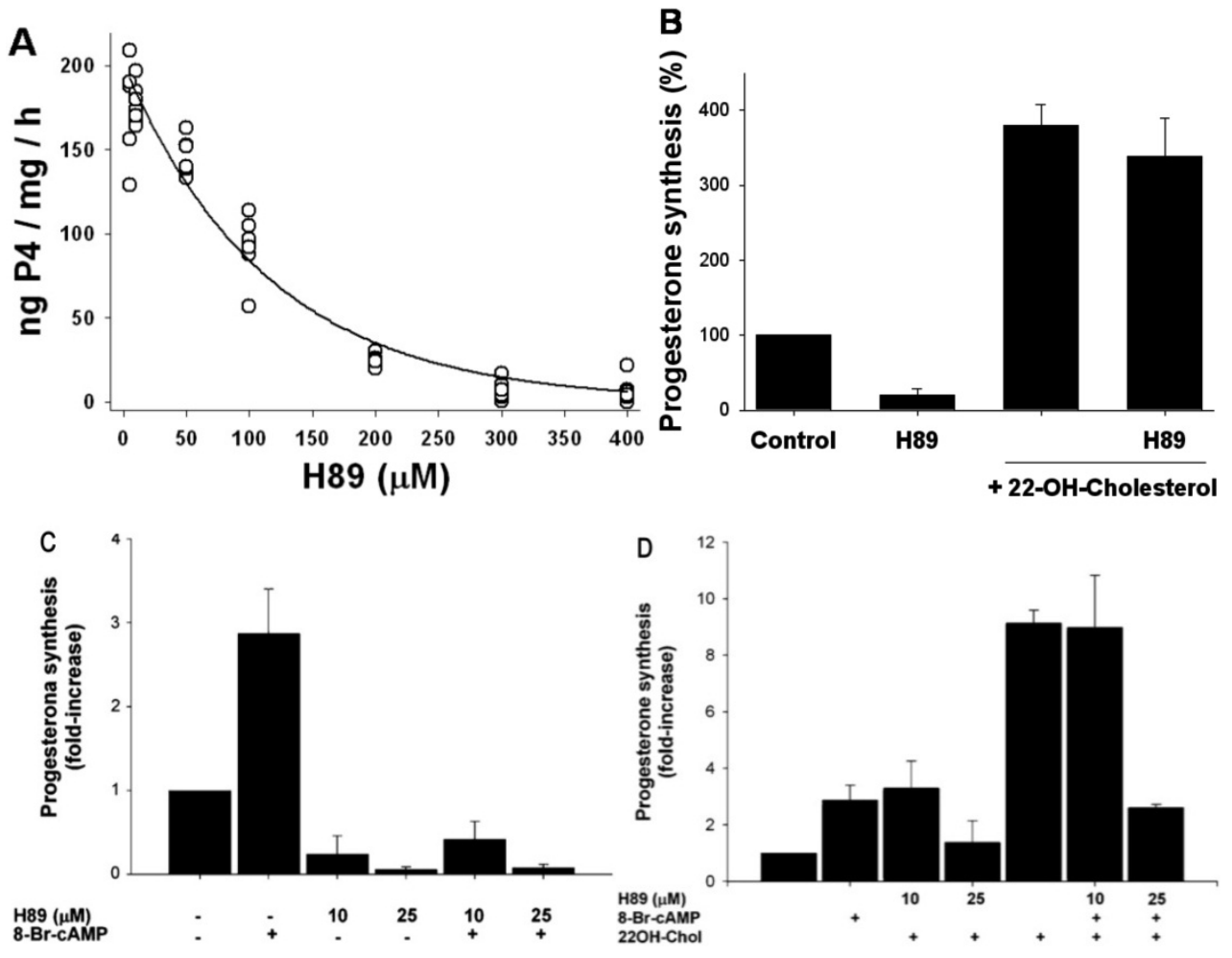

Fig. 9. Progesterone syntheses by syncytiotrophoblast mitochondria (A and B) and progesterone synthesis in BeWo cells (C and D) (see Material and Methods from Maldonado-Mercado et al., 2008, and Gómez-Concha et al., 2011). 22(R)-hydroxycholesterol (22-OH-Cholesterol or 22OH-Chol). 
Interestingly, in cultured human placenta cells, the stimulus of an acute signaling pathway associated with steroidogenesis as the one observed in isolated mitochondria has not been described; nevertheless it has been suggested that the pathway mediated by PKA/cAMP plays an important role in the regulation of placental steroidogenesis, perhaps with the potential participation of other signal transduction pathways, as it has been observed in other tissues (Dodge-Kafka \& Kapiloff, 2006). The endocrine, paracrine, autocrine, and even intracrine mechanisms that modulate this process are still to be described. No matter which one is the signaling pathway activated, the importance of the events of dynamic phosphorylation of proteins with pleiotropic effects in cellular functions as hormonal synthesis is the most relevant (Corso \& Thomson, 2001; Gorostizaga et al., 2007; Thomson, 2002).

\subsection{Protein phosphorylation in the control of steroidogenesis}

Protein phosphorylation is one of the most studied postranslational modifications. The modification of target proteins on specific residues allows structural changes, changes in the protein-protein interaction, and favors their activation or inactivation (Chang \& Karin, 2001), thus achieving the regulation of their functions (Matthews, 1995; Klumpp \& Krieglstein, 2005; Puttick et al, 2008).

It has been shown that the activity of certain proteins modulated by phosphorylation/ dephosphorylation has a temporary effect in specific cellular regions such as the plasma membrane, endoplasmic reticulum, and nucleus, regulating the cellular metabolism (Trost, 2010; Bauman \& Scott, 2002), a system that seems to be associated with steroidogenesis (Gómez-Concha et al., 2011), similar to StAR protein (Steroidogenic acute regulatory protein) in adrenal glands and gonads. StAR protein phosphorylation mediated by PKA stimulates the transport of cholesterol from the cytoplasm into mitochondrial membranes (Stocco, 2000; Thomson, 1998; Manna \& Stocco, 2005), apparently through a multiprotein complex associated to this organelle (Thomson, 2002) (Fig.10).

It has been suggested that a tyrosine phosphatases is the key for the regulation of StAR and the transport of cholesterol, where phosphorylation/dephosphorylation of intermediary proteins is fundamental in the regulation of steroids biosynthesis (Cooke et al, 2011). Although the placenta does not synthesize StAR protein, data suggest that trophoblast cells have a phosphorylation/dephosphorylation system associated with steroidogenesis.

It has been described that the PKA activity associated with mitochondria is different from that of cytoplasm, suggesting a differential regulation according to their subcellular location, maybe related to the complex formed by PKA, AKAP 121, and PTPD1 (Feliciello et al, 2001; Gómez-Concha et al., 2011). This way, the identification of proteins phosphorylated on their serine, tyrosine, and threonine residues suggests that the metabolism of placental mitochondria has important kinase activity (Gómez-Concha et al., 2011).

In BeWo cells and in isolated mitochondria from placenta, the phosphorylated proteins of 46, 42 and $36 \mathrm{kDa}$ appear to be a potential target of kinases and phosphatases system, where the H89 change the balance of phosphorylation/ dephosphorylation between proteins of 42 and 36 kDa (Maldonado-Mercado et al., 2008; Gómez-Concha et al., 2011) (Fig. 11 and 12). 


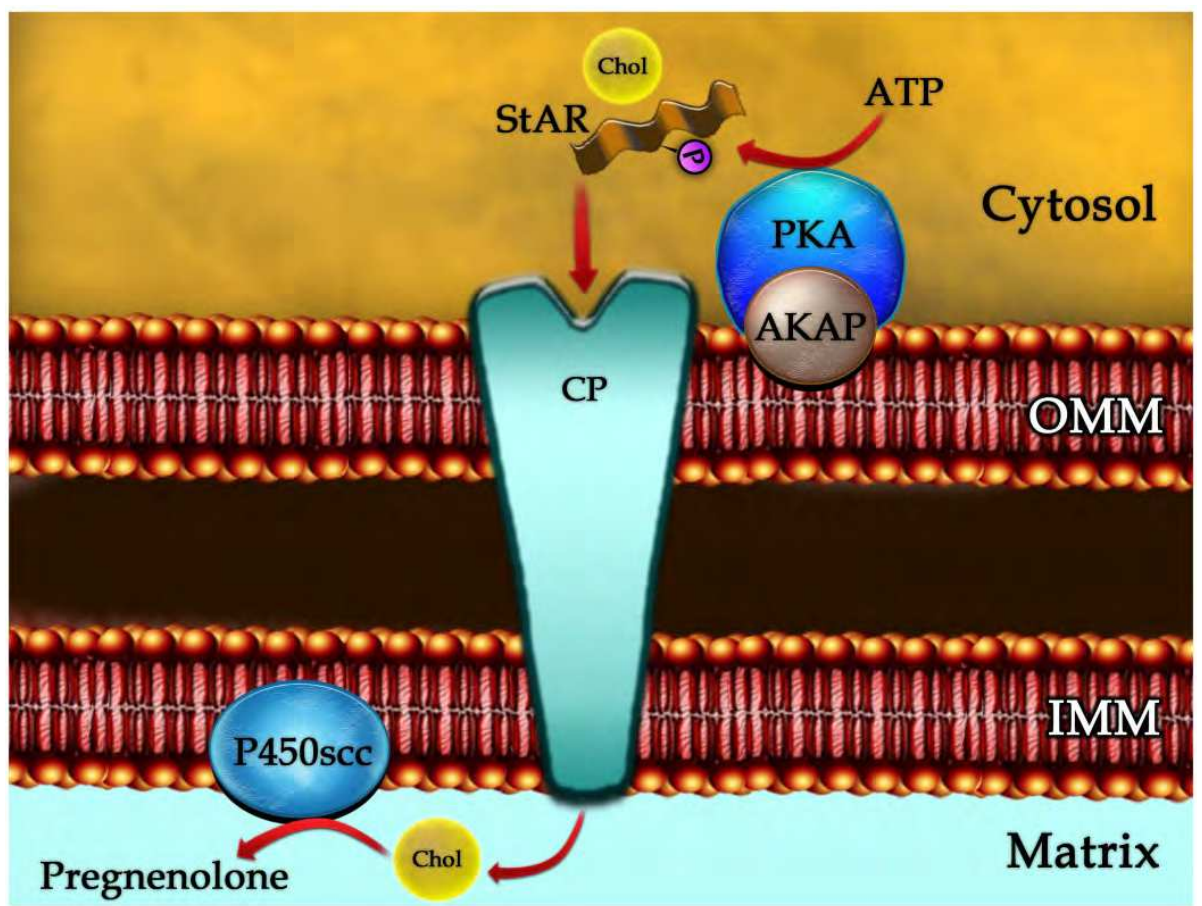

Fig. 10. Propose model for steroidogenic modulation by mitochondrial PKA (Modified from Thomson, 2002).
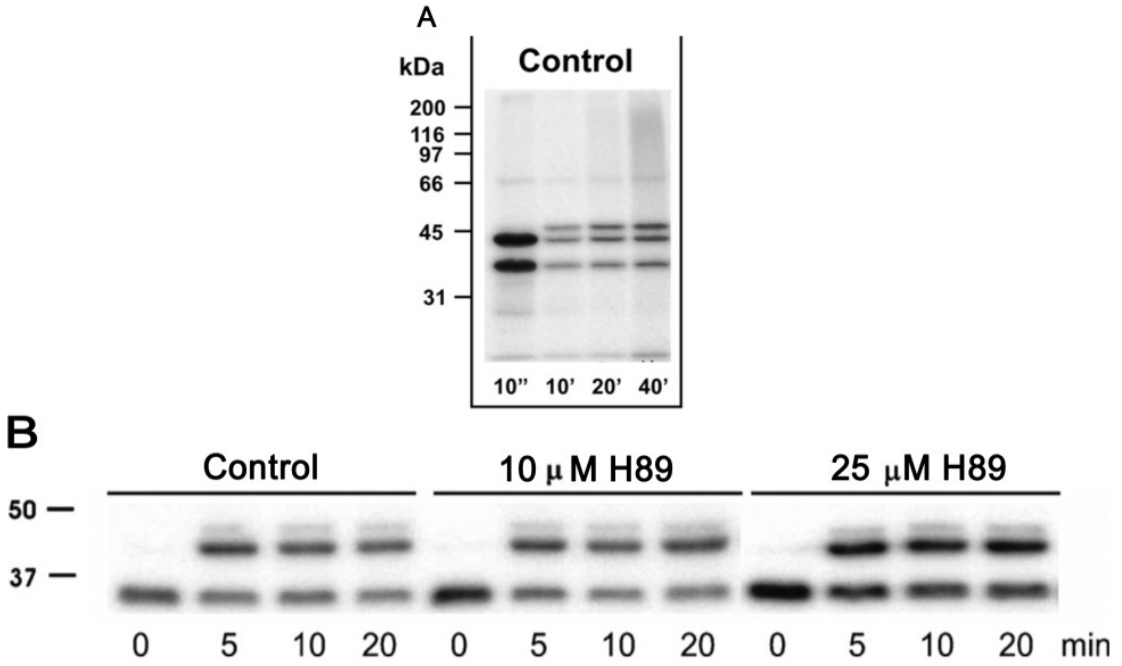

Fig. 11. Incorporation of $\left(\gamma^{32} \mathrm{P}\right)$ to syncytiotrophoblast mitochondria proteins $(\mathrm{A})$ and isolated mitochondria from BeWo cells in the presence of H89 (B). (see Material and Methods from Maldonado-Mercado et al., 2008; Gómez -Concha et al., 2011) 


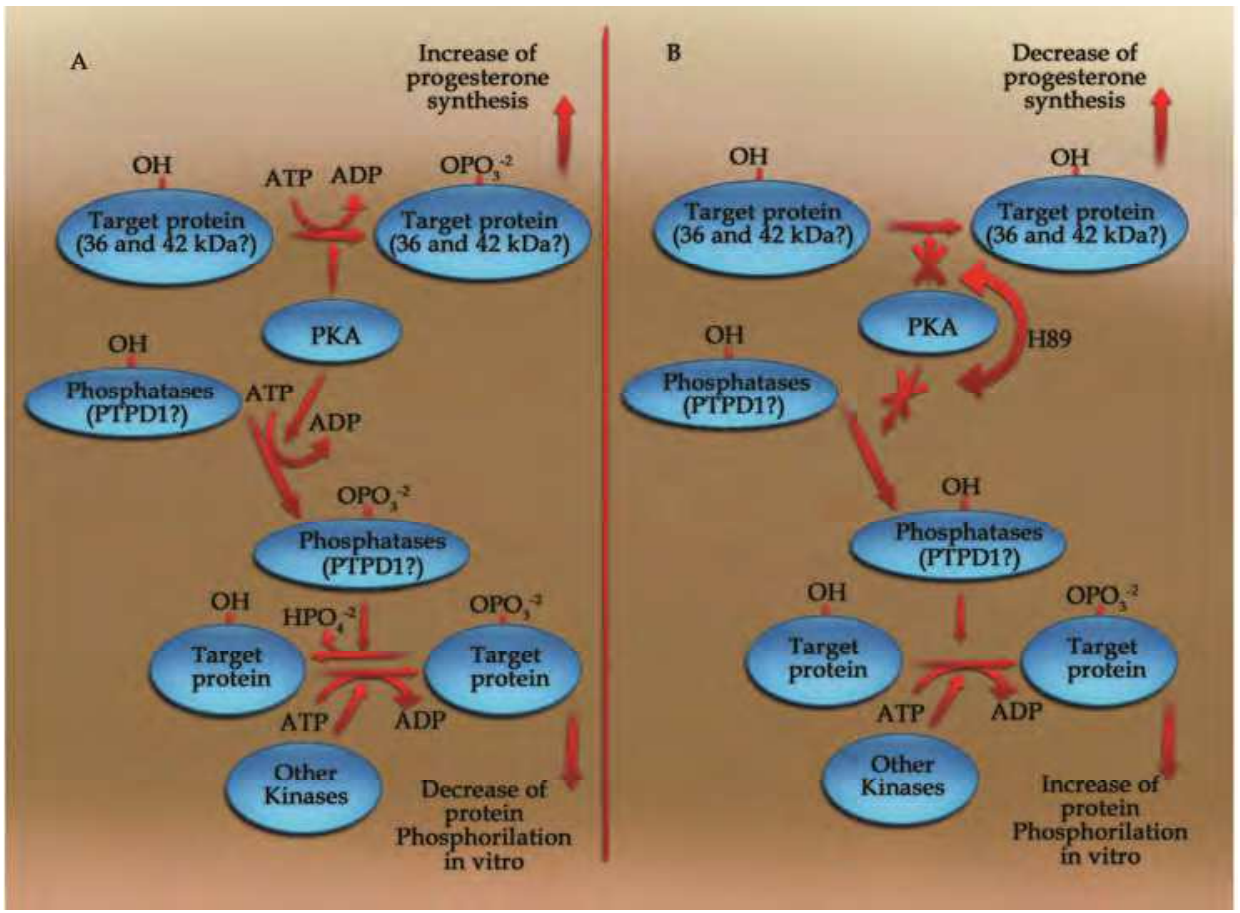

Fig. 12. Model proposed for the participation of PKA in steroidogenesis by syncytiotrophoblast mitochondria (Modified from Gómez -Concha et al., 2011).

\section{Steroidogenesis}

The transport of cholesterol to mitochondria by proteins is required for steroidogenesis. Deep differences between the placenta and adrenal glands have been observed, which are tightly associated to the permanent production of progesterone.

Meanwhile the cellular movement of cholesterol from cytoplasm to different organelles is accomplished by StAR, i.e. adrenal glands, gonads, liver, brain and others; human placenta does not express the StAR protein. A metastatic lymph node 64 protein (MLN64), which has similar characteristics to StAR protein to recognize cholesterol and transport it to the mitochondria, has been implicated in the movement of cholesterol in the human placenta; also, other proteins have been associated with cholesterol transport, such as the heat shock protein 60 (HSP60) (Olvera-Sanchez et al, 2011) and porine (Espinosa-Garcia et al., 2000).

In the previous sections of this chapter, several aspects of the trophoblast cells have been described. As it was observed, the human placenta possesses special characteristics basically oriented to maintain the relationship between mother and fetus in order to reach a successful delivery. The human placenta works as a mechanical barrier, being highly specific about the molecules that can cross it. In a sense, it controls by itself the mechanisms that regulate the metabolism and hormone production to assure nutrient supply by using different metabolic and signaling pathways, also modulating the mitochondrial activity 
through ATP-diphosphohydrolase and other enzymatic activities due to the relevant role that mitochondria play in both ATP synthesis and steroidogenesis.

As mentioned before, cholesterol is the source of steroid hormones, but the human placenta is unable to synthesize it, so the cholesterol must be obtained from mother's lipoproteins. During pregnancy, the amount of progesterone required is high, and during the first trimester its production is responsibility of the corpus luteum, while the egg implantation in the maternal epithelium of the uterus occurs.

\subsection{Electron transport chain coupled to cytochrome P450scc}

Placental steroidogenesis is an essential process for reproduction. Syncytiotrophoblast cells are the P4-producing cells in the human placenta (Martinez et al., 1997). By full-term pregnancy, placenta produces about $300 \mathrm{mg}$ of P4 per day (Strauss et al., 1996). The first enzymatic stage in its production is the conversion of cholesterol into P5 by P450scc type I (CYP11A1; EC 1.14.15.6), composed by approximately 530 amino acids, including the signal peptide necessary for its association to the mitochondrial inner membrane and only one heme group. P450scc receives six electrons from 3 moles of NADPH through a $54 \mathrm{kDa}$ flavoprotein, ferredoxin reductase (adrenodoxin reductase), and ferredoxin (adrenodoxin) a $2 \mathrm{Fe}-2 \mathrm{~S}$ protein with a molecular weight of $13.5 \mathrm{kDa}$. Both are found in the mitochondrial matrix. Studies of the molecular mechanism about the formation of this complex and electron transport have proposed a stoichiometry for proteins 1:1:1 or 1:2:1, and it has been suggested that adrenodoxin behaves as a mobile electron transporter from adrenodoxin reductase to P450scc (Miller, 2005), and the interaction between CYP11A and adrenodoxin reductase has been shown by molecular biology technics (Payne \& Hales, 2004; Strushkevicha, 2011) (Fig. 13).

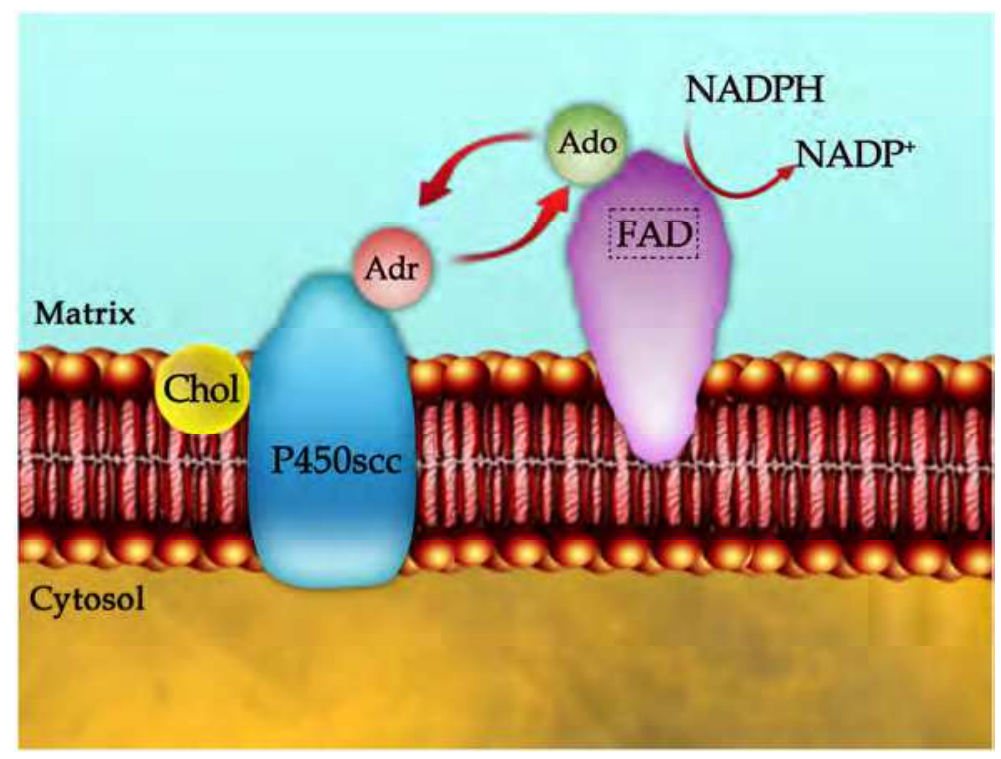

Fig. 13. Electron transport from adrenodoxin reductase to P450scc. Ado = adrenodoxin; Adr $=$ Adrenodoxin reduced; $\mathrm{FAD}=$ adrenodoxin reductase (Modified from Payne and Hales, 2004). 
The transformation of cholesterol into P5 requires three mono-oxygenation reactions, using molecular oxygen, involving two stereo-specific hydroxylations with the formation of $22(R)-$ hydroxycholesterol and 20(R),22(R)-dihydroxycholesterol followed by the breaking of the bond C-C between carbons 20 and 22 to release the lateral chain, yielding isocaproaldehyde and $\mathrm{P} 5$, which is changed into $\mathrm{P} 4$ through two consecutive reactions that require $\mathrm{NAD}^{+}$and are catalyzed by the same enzyme 3HSD type 1 (EC 5.3.3.1) with no release of intermediaries. Two isoenzymes of 3HSD are known in humans, product of different genes (Payne \& Hales, 2004). In the placenta, 3HSD is found in the mitochondria, unlike other steroiodogenic tissues in which it is found in the endoplasmic reticulum. The activity of this enzyme is higher than P450scc activity; therefore, it is not a limiting step in P4 synthesis (Tuckey, 2005). On the other hand, no disease involving the loss of 3HSD activity in the placenta is known, suggesting that its absence is incompatible with pregnancy.

\subsection{Systems for cholesterol transport and mitochondrial contact sites}

The cholesterol that participates in P4 synthesis comes from maternal circulation as lipoprotein complexes (LDL or HDL) which bind to their receptors in the plasma membrane. LDLs are released from their endosomal receptors to make late endosomes/lysosomes and obtain free cholesterol as substrate for P450scc (Hu et al., 2010).

The transport of cholesterol from the cytoplasm into the outer mitochondrial membrane in most steroidogenic tissues is associated to many proteins; the StAR, is the first protein identified as part of a family that contains the START domain (StAR-related lipid transfer domain) of about 210 amino acids. It is synthesized as a $37 \mathrm{kDa}$ protein with a signal peptide aimed to the mitochondrion to yield cholesterol to the outer mitochondrial membrane and, then is transformed into a $30 \mathrm{kDa}$ intramitochondrial protein (Manna \& Stocco, 2005). This protein is phosphorylated and activated in response to hormonal stimulation in steroidogenic cells (Arakane et al., 1996). The constructs lacking the 62 amino acid residues from the amino-terminal of StAR yields a truncated protein still able to participate in steroidogenesis. These results suggest that the translocation of the StAR protein to the interior of the mitochondria is not a requisite for cholesterol transport, and suggests that cholesterol may be transferred to another soluble acceptor protein or transporter in the outer mitochondrial membrane which finally allows it to reach P450scc for P4 synthesis (Bose et al., 2000; Alpy \& Tomasetto, 2006). Nevertheless, the human placenta does not express StAR, and it has been proposed that the protein MLN64 (Moog-Lutz, 1997) could perform the activity of cholesterol transporter. MLN64 is a $54 \mathrm{kDa}$ protein (445 amino acids), isolated from a metastatic nodule of breast cancer. MLN64 is found in late endosomes and has two functional domains, one in the amino end with four transmembrane domains and another at the carboxyl end, corresponding to the START domain, oriented towards the cytoplasm, composed by 227 amino acids with an identity of $37 \%$ of StAR sequence. The tridimensional organization of its crystals shows the formation of a hydrophobic tunnel which allows the collocation of one molecule of cholesterol. This location supports the theory of MLN64 substituting StAR in human placenta to promote the flow of cholesterol.

Full-term human placenta isolated mitochondria synthesize P4 without the addition of exogenous cholesterol (Martinez et al., 1997). It has been reported that cholesterol transport between human placenta mitochondrial membranes requires proteins, since when treated with trypsin they are unable to transport cholesterol and, therefore, synthesize P4. 
Nevertheless, mitochondria treated with trypsin were able to efficiently transform $22(R)$ hydroxycholesterol into $\mathrm{P} 4$, a substrate that does not need a protein membrane transport system, showing that the P450scc chain is not modified by such treatment; thus making human placenta isolated mitochondria an adequate model for the study of cholesterol transport and steroidogenesis (Espinosa-García et al., 2000).

The transport of cholesterol towards the inner mitochondrial membrane requires many proteins associated with the contact sites; these are dynamic structures formed by proteins coming from both the outer and inner membrane and work as complexes that are assembled and degraded according to specific mitochondria conditions. Hence, contact sites might represent the most efficient route for cholesterol to reach P450scc (Thomson, 2003).

It has been reported that during the isolation of mitochondrial contact sites from full-term human placenta, 3 fractions were obtained from the outer membrane and 4 from the inner membrane. The protein composition was specific for each one of them and only one fraction of the inner membrane was able to transform cholesterol into P4. In such fraction, reported as steroidogenic site, porine, creatine kinase, the translocator of adenine nucleotides, ATPdiphosphohydrolase, MLN64, and HSP90, HSP72, HSP40 and HSP27, enzymes of the P450scc chain, and NADP+-dependent isocitrate dehydrogenase were identified. These results support the theory that binding sites are an efficient system for cholesterol transit in the human placenta mitochondria (Uribe et al., 2003) (Fig. 14).

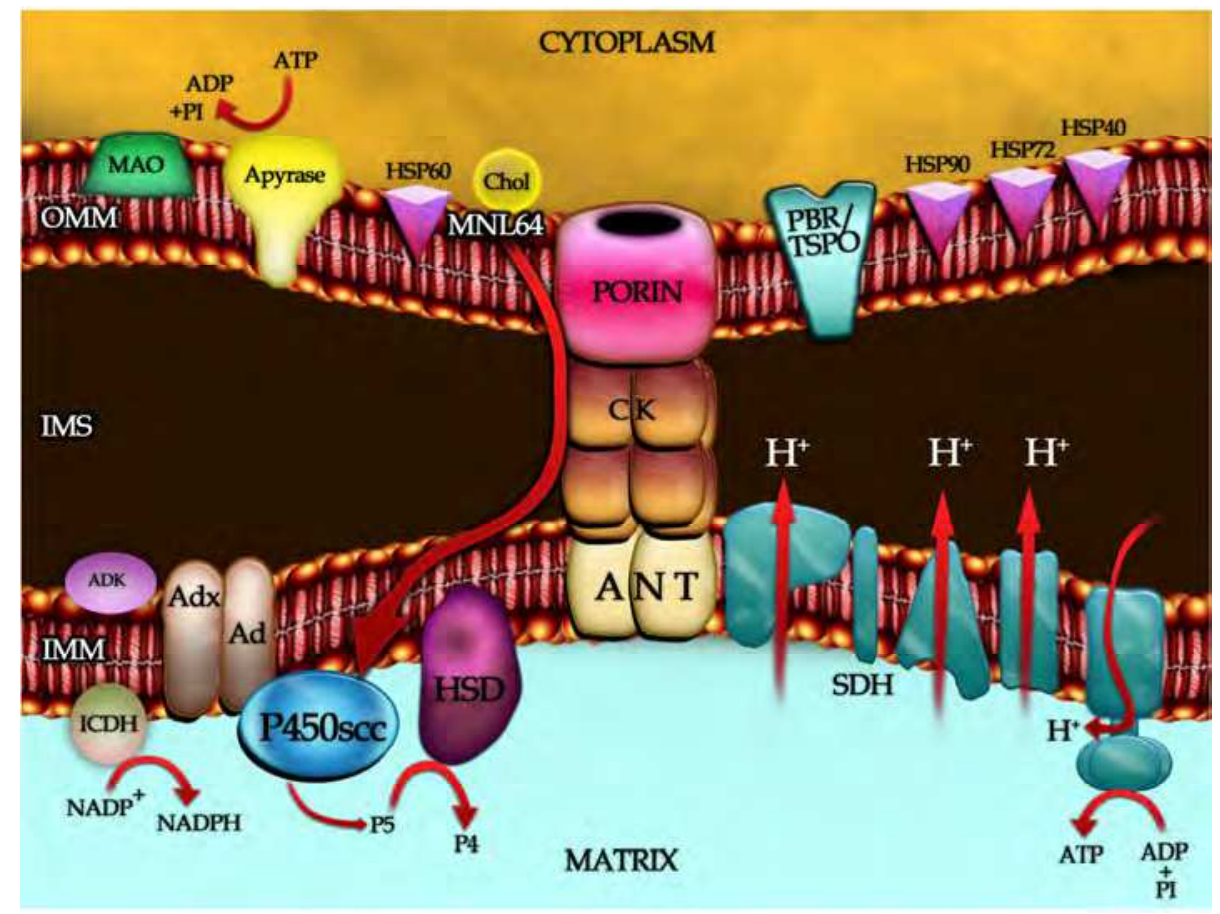

Fig. 14. Model of isolated contact sites from human placental syncytiotrophoblast mitochondria. (Modified from Uribe et al., 2003). 
The use of MLN64 antibodies allowed the recognition of a $60 \mathrm{KDa}$ protein identified as an HSP and another $30 \mathrm{kDa}$ protein corresponding to the START domain of MLN64, in human placenta isolated mitochondria. Results suggest that both proteins participate in placental seteroidogenesis, favoring both cholesterol movement towards mitochondrial membranes and the release of P4 from mitochondria (Olvera-Sanchez et al., 2011).

\subsection{Steroidogenesis regulation}

$\mathrm{P} 4$ biosynthesis regulation in placenta seems to be at two levels. One is related to hormones and/or factors currently unknown, which initiates a signal transduction cascade involving PKA activation cAMP mediated, as explained before, and another level involving the mitochondria.

As for the mechanism at mitochondrial level, it has been proposed that the activity of P450scc might be regulated by the concentration of adrenodoxin reductase which causes a decrease of P450scc affinity for cholesterol, and makes it work just at $16 \%$ of its capacity (Tuckey \& Headlam, 2002). Nevertheless, the results obtained from mitochondria isolated from the placenta in the presence of 22(R)-hydroxycholesterol show no limitation in their capacity to produce P4. Therefore, it is unlikely that in physiologic conditions the activity of adrenodoxin reductase is a controlling factor.

Just like other steroidogenic tissues, the limiting step in P4 production is the access of cholesterol to mitochondria. So far, no evidence of any protein limiting transport is available, surely because it would be incompatible with pregnancy. Data available suggest that placental cells have the necessary mechanisms to allow cholesterol to reach mitochondria constantly, making P4 synthesis a constitutive metabolic pathway that assures, independently of nutritional conditions, physical or related to mother's health, that the fetus reaches the full term of pregnancy. In this context, the knowledge of the endocrine, paracrine, etc., signaling pathways would allow the development of therapeutic strategies that favor the integral development of the fetus.

Nevertheless, it is important to mention that acute regulation at mitochondrial level is necessarily accompanied by a chronic modulation mediated by the control of the transcription/translation of the genes that encode for the different steroidogenic enzymes, in a tissue-specific fashion. As for the placenta, it has been observed that there are mechanisms controlling the expression of the genes of the steroidogenic enzymes in which cAMP has no prominent role.

In gonads or adrenal glands, mutations of the genes encoding for proteins STARD1, CYP11A1 or 3HSD affects steroid production, being SF-1 the main factor regulating P450scc expression (Schimmer \& White, 2010). Nevertheless, SF-1 factor is not found in human placenta. It has been suggested that P450scc expression is regulated by AP-2 factors that bind to cis elements overlapped to the sequences required for the recognition of SF-1 in other steroidogenic tissues (Ben-Zimra, 2002). It has also been proposed that LBP (Long Terminal Repeat Binding Proteins) identified in the syncytiotrophoblast might assume the regulator role of SF-1, binding to the region -155 to -131 of the promoter of the genes that allow the expression of P450scc. LBP-1b would act as an activator of the expression of P450scc, whereas LBP-9 and LBP-32 would act as repressors (Henderson et al., 2008; LaVoie \& King., 2009). 


\section{Conclusion}

On the whole, the information shows that mitochondria isolated from human placenta are an appropriate model to study the mechanisms of cholesterol transport. The physiological difference between human placenta and other steroidogenic organs make the human syncytiotrophoblast a particular tissue, which maintains a functional independence while allowing the interaction between the mother and the fetus to successfully reach the full term of pregnancy in order to perpetuate the species.

\section{Acknowledgements}

The present work has the partial support of DGAPA, UNAM (IN202496, IN200399, IN203006, IN 217609), and CONACYT (26096M). The author thanks Dr. José Luis PérezGarcía in the translation of the present chapter.

\section{References}

Aldoreta, P.W. \& Hay, W.W. (1995). Metabolic Substrates for Fetal Energy Metabolism and Growth. Clinics in Perinatology, Vol.22, No.1, (March 1995), pp.15-37, ISSN 00955108

Allen, J.A; Shankara, T.; Janus, P.; Buck, S.; Diemer, T.; Hales, K.H. \& Hales, D.B. (2006). Energized, Polarized, and Actively Respiring Mitochondria are Required for Acute Leydig Cell Steroidogenesis. Endocrinology, Vol.147, No.8, (August 2006), pp. 39243935, ISSN 0013-7227

Alpy, F. \& Tomasetto, C. (2006). MLN64 and MENTHO, Two Mediators of Endosomal Cholesterol Transport. Biochemical Society Transactions, Vol. 34, Pt.3, (June 2006), pp. 343- 345, ISSN 0300-5127

Angiolini, E.; Fowden, A.; Coan, P.; Sandovici, I.; Smith, P.; Dean, W.; Burton, G.; Tycko, B.; Reik, W.; Sibley, C. \& Contância, M. (2006). Regulation of Placental Efficiency for Nutrient Transport by Imprinted Genes. Placenta, Vol.27, Suppl A, (April 2006), pp. S98-102, ISSN 0143-4004

Arakane, F.; Sugawara, T.; Nishino, H.; Liu, Z.; Holt, J.A.; Pain, D.; Stocco, D.M.; Miller, W.L. \& Strauss J.F. 3rd. (1996). Steroidogenic Acute Regulatory Protein (StAR) Retains Activity in the Absence of its Aitochondrial Import Sequence: Implications for the Mechanism of StAR Action. Proceedings of the National Academy of Sciences. U.S.A., Vol. 93, No. 24, (November 1996), pp. 13731-13736, ISSN 0027-8424

Arnold, I.; Pfeiffer, K.; Neuport, W.; Stuart, R.A. \& Schägger, H. (1998). Yeast Mitochondrial F1F0-ATP Synthase Exists as a Dimer: Identification of Three Dimer-Specific Subunits. The EMBO Journal, Vol.17, No.24, (December 1998), pp. 7170- 7178, ISSN 0261-4189

Barash, V.; Reskin, A.; Shafrir, E.; Waddell, I.D. \& Burchell, A. (1991). Kinetic and Immunologic Evidence for the Absence of Glucose-6-phosphatase in Early Human Chorionic Villi and Term Human Placenta. Biochimica et Biophysica Acta, Vol.1073, No.1, (January 1991), pp. 161-167, ISSN 0304-4165

Battaglia, F.C. (1989). An Update Off and Placental Metabolism: Carbohydrate and Amino Acids. Biology of the Neonate, Vol.55, No.6, pp. 347-354, ISSN 0006-3126 
Bauman, A.L. \& Scott, J.D. (2002). Kinase- and Phosphatase-Anchoring Proteins: Harnessing the Dynamic Duo. Nature Cell Biology, Vol.4, No.8, (August 2002), pp. E203-E206, ISSN1465-7392

Ben-Zimra, M.; Koler, M. \& Orly, J. (2002). Transcription of Cholesterol Side-Chain Cleavage Cytochrome P450 in the Placenta: Activating Protein-2 Assumes the Role of Steroidogenic Factor-1by Binding to an Overlapping Promoter Element. Molecular Endocrinology, Vol.16, No.8, (August 2002), pp. 1864-1880, ISSN 0888-8809

Bloxam, D.L. \& Bobinski, P.M. (1984). Energy Metabolism and Glycolysis in the Human Placenta During Ischaemia and in Normal Labour. Placenta, Vol.5, No.5, (September-October 1984), pp. 381-394, ISSN 0143-4004

Bose, H.S.; Whittal, R.M.; Huang, M.C.; Baldwin, M.A. \& Miller, W.L. (2000). N-218 MLN64, a Protein with StAR-like Steroidogenic Activity, Is Folded and Cleaved Similarly to StAR. Biochemistry, Vol.39, No.38, (September 2000), pp. 11722-11731, ISSN 00062960

Brand, C.; Cherradi, N.; Defaye, G.; Chinn, A.; Chambaz, E.M.; Feige, J.J. \& Bailly, S. (1998). Transforming Growth Factor Beta1 Decreases Cholesterol Supply to Mitochondria Via Repression of Steroidogenic Acute Regulatory Protein Expression. Journal of Biological Chemistry, Vol.273, No.11, (March 1998), pp. 6410-6416, ISSN 0021-9258

Cabezón, E.; Arechaga, I.; Jonathan, P.; Butler, G. \& Walker, J.E. (2000). Dimerization of Bovine F1-ATPase by Binding the Inhibitor Protein, IF1. Journal of Biological Chemistry, Vol.275, No.37, (September 2000), pp. 28353-28355, ISSN 0021-9258

Cammer, W. \& Estabrook, R.W. (1967). Spectrophotometric Studies of the Pigments of Adrenal Cortex Mitochondria. Archives of Biochemistry and Biophysics, Vol.122, No.3, (December 1967), pp. 735-747, ISSN 0003-9861

Campanella, M.; Casswell, E.; Chong, S.; Farah, Z.; Wieckowski, M.R.; Abramov, A.; Y. Tinker, A. \& Duchen, M.R. (2008). Regulation of Mitochondrial Structure and Function by the F1Fo-Atpase Inhibitor Protein, IF1. Cell Metabolism, Vol.8, No.1, (July 2008), pp. 13-25. ISSN 1550-4131

Carter, A.M. (2000). Placental Oxygen Consumption. Part I: in vivo Studies-a Review. Placenta, Vol.21, Suppl. A, (March-April 2000), pp. S31-37, ISSN 0143-4004

Chang, L. \& Karin, M. (2001). Mammalian MAP Kinase Signalling Cascades. Nature, Vol.410, No.6824, (March 2001), pp. 37-40, ISSN0028-0836

Cherradi, N.; Defaye, G. \& Chambaz, E.M. (1994). Characterization of the 3 betahydroxysteroid dehydrogenase Activity Associated With Bovine Adrenocortical Mitochondria. Endocrinology, Vol.134, No.3, (March 1994), pp. 1358-1364. ISSN 0013-7227

Clarson, L.H.; Glazier, J.D.; Sides, M.K. \& Sibley, C.P. (1997). Expression of the Facilated Glucose Transporters (GLUT1 and GLUT3) by a Choriocarcionoma Cell Line (Jar) and Cytotrophoblast Cell in Culture. Placenta, Vol.18, No.4, (May 1997), pp. 333339, ISSN 0143-4004

Coleman, R.A. (1986). Placental Metabolism and Transport of Lipids. Federation Proceedings, Vol.45, No.10, (September 1986), pp. 2519-2523, ISSN 0014-9446

Cooke, M.; Mele, P.; Maloberti, P.; Duarte, A.; Poderoso, C.; Orlando, U.; Paz, C.; Cornejo Maciel, F. \& Podestá, E.J. (2011). Tyrosine Phosphatases as Key Regulators of Star Induction and Cholesterol Transport: SHP2 as a Potential Tyrosine Phosphatase 
Involved in Steroid Synthesis. Molecular and Cellular Endocrinology, Vol.336, No.1-2, (April 2011), pp. 63-69, ISSN 0303-7207

Corso, M. \& Thomson, M. (2001). Protein Phosphorylation in Mitochondria from Human Placenta. Placenta, Vol.22, No.5, (May 2001), pp. 432-439, ISSN 0143-4004

Cunningham, P. \& McDermott, L. (2009). Long Chain PUFA Transport in Human Term Placenta. The American Journal of Clinical Nutrition, Vol.139, No.4, (February-April 2009), pp. 636-639, ISSN 0002-9165

De Los Rios Castillo, D.; Zarco-Zavala, M.; Olvera-Sanchez, S.; Pardo, J.P.; Juarez, O.; Martinez, F.; Mendoza-Hernandez, G.; García-Trejo J.J. \& Flores-Herrera O. (2011). Atypical Cristae Morphology of Human Syncytiotrophoblast Mitochondria. Role for Complex V. The Journal of Biological Chemistry. Vol.286, No.27, (July 2011), pp. 23911-23919, ISSN 0021-9258

Desoye, G. \& Shafrir, E. (1994). Placental Metabolisms and its Regulation in Health and Diabetes. Molecular Aspects of Medicine, Vol.15, No.6, pp. 505-682, ISSN 0098-2997

Dodge-Kafka, K.L. \& Kapiloff, M.S. (2006). The mAKAP Signaling Complex: Integration of AMPc, Calcium, and MAP Kinase Signaling Pathways. European Journal of Cell Biology, Vol.85, No.7, (July 2006), pp.593-602, ISSN 0171-9335

Dominguez-Ramirez, L.; Mendoza-Hernandez, G.; Carabez-Trejo, A.; Gomez-Puyou, A. \& Tuena de Gomez-Puyou, M. (2001). Equilibrium Between Monomeric and Dimeric Mitochondrial F1-inhibitor Protein Complexes. FEBS Lett, Vol.507, No.2, (October 2001), pp. 191- 194, ISSN 0014-5793

Duan. L.; Yan, D.; Zeng, W.; Yang, X. \& Wei, Q. (2010). Effect of Progesterone Treatment Due to Threatened Abortion in Early Pregnancy for Obstetric and Perinatal Outcomes. Early Human Development, Vol.86, No.1, (January 2010), pp. 41-3, ISSN 0378-3782

Dudkina, N.V.; Heinemeyer, J.; Keegstra, W.; Boekema, E.J. \& Braun, H.P. (2005). Structure of Dimeric ATP Synthase from Mitochondria: an Angular Association of Monomers Induces the Strong Curvature of the Inner Membrane. FEBS Lett, Vol.579, No.25, (October 2005), pp. 5769-5772, ISSN 0014-5793

Dyson, M.T.; Jones, J.K.; Kowalewski, M.P.; Manna, P.R.; Alonso, M.; Gottesman, M.E. \& Stocco, D.M. (2008). Mitochondrial A-Kinase Anchoring Protein 121 Binds Type II Protein Kinase A and Enhances Steroidogenic Acute Regulatory Protein-Mediated Steroidogenesis in MA-10 Mouse Leydig Tumor Cells. Biology of Reproduction, Vol.78, No.2, (February 2008), pp. 267-77, ISSN 0006-3363

Espinosa-Garcia, M.T.; Strauss J.F. III \& Martinez, F. (2000). A Trypsin-Sensitive Protein is Required for Utilization of Exogenous Cholesterol for Pregnenolone Synthesis by Placental Mitochondria. Placenta, Vol.21, No.7, (September 2000), pp. 654 -660, ISSN 0143-4004

Fei, Y.J.; Prasad, P.D.; Leibach, F.H. \& Ganapathy, V. (1995). The Amino Acid Transport System $\mathrm{y}^{+} \mathrm{L}$ Induced in Xenopus laevis Oocytes by Human Choriocarcinoma Cell (JAR) mRNA is Functionally Related to the Heavy Chain of the 4F2 Cell Surface Antigen. Biochemistry, Vol.34, No.27, (July 1995), pp. 8744-8751, ISSN 0006-2960

Feliciello, A.; Gottesman, M.E. \& Avvedimento, E.V. (2001). The Biological Functions of Akinase Anchor Proteins. Journal of Molecular Biology, Vol.308, No.2, (April 2001), pp. 99-114, ISSN 0022-2836 
Feliciello, A.; Gottesman, M.E. \& Avvedimento EV. (2005). cAMP-PKA Signaling to the Mitochondria: Protein Scaffolds, mRNA and Phosphatases. Cell Signal, Vol.17, No.3, (March2005), pp. 279-87, ISSN 0898-6568

Flores-Herrera, O.; Uribe, A.; Pardo, J.P.; Rendón, J.L. \& Martinez, F. (1999). A Novel ATPdiphosphohydrolase from Human Term Placental Mitochondria. Placenta, Vol.20, No.5-6, (July-August 1999), pp. 475-484, ISSN 0143-4004

Flores-Herrera, O.; Uribe, A.; García-Pérez, C.; Milán, R. \& Martinez, F. (2002). 5-pFluorosulfonylbenzoyl Adenosine Inhibits Progesterone Synthesis in Human Placental Mitocondria. Biochimica et Biophysica Acta, Molecular and Cell Biology of Lipids, Vol.1585, No.1, (November 2002), pp. 11-18, ISSN 1388-1981

García, J.J.; Morales-Ríos, E.; Cortés-Hernandez, P. \& Rodríguez-Zavala, J.S. (2006). The Inhibitor Protein (IF1) Promotes Dimerization of the Mitochondrial F1F0-ATP Synthase. Biochemistry, Vol.45, No.42, (October 2006), pp. 12695-12703, ISSN 00062960

García-Pérez, C.; Pardo, J.P. \& Martinez, F. (2002). Ca(2+) Modulates Respiratory and Steroidogenic Activities of Human Term Placental Mitochondria. Archives of Biochemistry and Biophysics, Vol.405, No.1, (September 2002), pp. 104-111, ISSN00039861

Garlid, K.D. \& Paucek, P. (2003). Mitochondrial Potassium Transport: the $\mathrm{K}^{+}$Cycle. Biochimica et Biophys Acta, Bioenergetics, Vol.1606, No.1-3, (September 2003), pp. 2341, ISSN 0005-2728

Gómez-Concha, C.; Flores-Herrera, O.; Olvera-Sanchez, S.; Espinosa-Garcia, M.T. \& Martinez, F. (2011). Progesterone Synthesis by Human Placental Mitochondria is Sensitive to PKA Inhibition by H89. The International Journal of Biochemistry \& Cell Biology, Vol.43 No.9, (September 2011), pp. 1402-11, ISSN: 1357-2725

Gordon-Smith, D.J.; Carbajo, R.J.; Yang, J.; Videler, H.; Runswick, M.J.; Walker, J.E. \& Neuhaus, D. (2001). Solution Structure of a C-terminal Coiled-coil Domain From Bovine IF(1): the Inhibitor Protein of F(1) ATPase. Journal of Molecular Biology, Vol.308, No.2, (April2001), pp. 325-339, ISNN 0022-2836

Gorostizaga A, Cornejo Maciel F, Brion L, Maloberti P, Podestá EJ, \& Paz C. (2007). Tyrosine Phosphatases in Steroidogenic Cells: Regulation and Function. Molecular and Cellular Endocrinology, Vol.265-266, (February 2007), pp. 131-137, ISSN 0303-7207

Hahn, T.; Barth, S.; Weiss, U.; Mosgoeeller, W. \& Desoye, G. (1998). Sustained Hyperglycemia In Vitro Down-Regulates the GLUT1 Glucose Transport System of Cultured Human Term Placental Trophoblast: a Mechanism to Protect Fetal Development? Federation of American Societies for Experimental Biology, Vol. 12, No.12, (September 1998), pp. 1221-1231, ISSN 0892-6638

Hahn, T.; Barth, S.; Graf, R.; Engelmann, M.; Beslagic, D.; Reul, J.M.; Holsboer, F.; Dohr, G. \& Desoye, G. (1999). Placenta Glucose Transport Expression is Regulated by Glucorticoids. The Journal of Clinical Endocrinology and Metabolism, Vol. 84, No.4, (April 1999), pp. 1445-1452, ISSN 0021-972X

Hackenbrock, C.R. (1968). Ultrastructural Bases for Metabolically Linked Mechanical Activity in Mitochondria. II. Electron Transport-linked Ultrastructural Transformations in Mitochondria. The Journal of Cell Biology, Vol.37, (May 1968), No.2, pp. 345-69, ISSN 0021-9525 
Hackenbrock, C.R.; Rehn, T.G.; Weinbach, E.C. \& Lemasters, J.J. (1971). Oxidative Phosphorylation and Ultrastructural Transformation in Mitochondria in the Intact Ascites Tumor Cell. The Journal of Cell Biology, Vol.51, (October 1971), No. 1, pp. 123-37, ISSN 0021-9525

Hanguel, S.; Dezmaizieres, V. \& Challier, J.C. (1986). Glucose Uptake, Utilization, and Transfer by The Human Placenta As Functions of Maternal Glucose Concentration. Pediatric Research, Vol.20, No.3, (March 1986), pp. 269-273, ISSN 0031-3998

Hanukoglu, I. \& Hanukoglu, Z. (1986). Stoichiometry of Mitochondrial Cytochromes P-450, Adrenodoxin and Adrenodoxin Reductase in Adrenal Cortex and Corpus Luteum. Implications for Membrane Organization and Gene Regulation. European Journal of Biochemistry, Vol.157, No.1, (Mayo 1986), pp. 27-31, ISSN 0014-2956

Harding, B.W. \& Nelson, D.H. (1966). Electron Carriers of the Bovine Adrenal Cortical Respiratory Chain and Hydroxylating Pathways. The Journal of Biological Chemistry, Vol.241, No.10 (May 1966), pp. 2212-2219, ISSN 1864-6158

Henderson,Y C.; Frederick, M.J.; Wang, M.T.; Hollier, L.M. \& Clayman, G.L. (2008). LBP-1b, LBP-9, and LBP-32/MGR Detected in Syncytiotrophoblasts from First-Trimester Human Placental Tissue and Their Transcriptional Regulation. DNA and Cell Biology, Vol.27, No.2, (February 2008), pp. 71-79, ISSN 1044-5498

Hoeltzli, S.D. \& Smith, C.H. (1989). Alanine Transport System in Isolated Basal Plasma Membrane of Human Placenta. The American Journal of Physiology, Vol.256, No.3Pt1, (March 1989), pp. C630-C637, ISSN 0002-9513

Hornstra, G.; Al, M.D.; van Houwelingen, A.C. \& Foreman-van D. (1995). Essential Fatty Acids in Pregnancy and Early Human Development. European Journal of Obstetrics and Gynecology and Reproductive Biology, Vol.61, No.1, (July 1995), pp. 57-62, ISNN 0301-2115

Hu, J.; Zhang, Z.; Shen, W.J. \& Azhar, S. (2010). Review Cellular Cholesterol Delivery, Intracellular Processing and Utilization for Biosynthesis of Steroid Hormones. Nutrition and Metabolism, Vol.7, (June 2010), pp. 47- 72, ISSN 1743-7075

Ingermann, R.L. (1987). Control of Placental Glucose Transfer. Placenta, Vol.8, no.6, (November-December 1987), pp. 557-571, ISSN 0143-4004

Jefcoate, C.R.; Simpson, E.R.; Boyd, G.S.; Brownie, A.C. \& Orme-Johnson, W.H. (1973). The Detection of Different States of the P-450 Cytochromes in Adrenal Mitochondria: Changes Induced by ACTH. Annals of the New York Academy of Sciences, Vol.212, (June 1973), pp. 243-61, ISSN 0077-8923

Kahn, B.B \& Flier, J.S. (1990). Regulation of Glucose-Transporter Gene Expression in Vitro and In Vivo. American Diabetes Association, Vol.13, No. 6, (June 1990), pp. 548-564, ISSN 0149-5992

Kasugai M, Kato H, Iriyama H, Kato M, Ninagawa T, \& Tomoda Y. (1987). The Roles of $\mathrm{Ca} 2+$ and Adenosine 3', 5'-Monophosphate in the Regulation of Progesterone Production by Human Placental Tissue. The Journal of Clinical Endocrinology $\mathcal{E}$ Metabolism, Vol.65, No.1, (July 1987), pp. 122-126, ISSN0021-972X

Lavy, G.; Barnea, E.R. \& Decherney, A.H. (1987). The Effect of Insulin on Oestradiol and Progesterone Release by Normal and Diabetic Placentae In Vitro. Placenta, Vol.8, No.4, (July-August 1987), pp. 443-8, ISSN 0143-4004 
LaVoie, H.A. \& King, S.R. (2009). Transcriptional Regulation of Steroidogenic Genes: STARD1, CYP11A1 and HSD3B. Experimental Biology and Medicine. Vol.234, No.8, (August 2009), pp. 880-907, ISSN 1535-3702

Maldonado-Mercado, G.; Espinosa-Garcia, M.T.; Gomez-Concha, C.; Monreal-Flores, J. \& Martinez, F. (2008). Steroidogenesis in BeWo Cells: Role of Protein Kinase A and Benzodiazepines. The International Journal of Biochemistry \& Cell Biology, Vol. 40, No.5, pp. 901-908, ISSN 1357-2725

Malka, F.; Guillery O.; Cifuentes-Diaz, C.; Guillou, E.; Belenguer, P.; Lombes, A. \& Rojo, M. (2005). Separate Fusion of Outer and Inner Mitochondrial Membranes. European Molecular Biology Organization reports, Vol.6, (September 2005), No.9, pp.853-859, ISSN 1469-221X

Manna, P.R. \& Stocco, D.M. (2005). Regulation of the Steroidogenic Acute Regulatory Protein Expression: Functional and Physiological Consequences. Current Drug Targets-Immune. Endocrine E Metabolic Disorders, Vol.5, No.1, (March 2005), pp. 93 108, ISSN 1568-0088

Manna, P.R.; Chandrala, S.P.; Jo, Y. \& Stocco, D.M. (2006). cAMP-Independent Signaling Regulates Steroidogenesis in Mouse Leydig Cells in the Absence of StAR Phosphorylation. Journal of Molecular Endocrinology, Vol.37, No.1, (August 2006), pp. 81-95, ISSN 0952-5041

Manna, P.R.; Dyson, M.T. \& Stocco, D.M. (2009). Regulation of the Steroidogenic Acute Regulatory Protein Gene Expression: Present and Future Perspectives. Molecular Human Reproduction, Vol.15, No.6, 8June 2009), pp. 321-33 ISSN 1360-9947

Mannella, C.A.; Marko, M.; Penczek, P.; Barnard, D. \& Frank, J. (1994). The Internal Compartamentation of Rat-Liver Mitochondria: Tomographic Study Using the High-Voltage Transmission Electron Microscope. Microscopy Research Technique, Vol.27, No.4, (March 1994), pp. 278-283, ISSN 1097-0029

Mannella, C.A.; Marko, M. \& Buttle, K. (1997). Reconsidering Mitochondrial Structure: New Views of an Old Organelle. Trends in Biochemical Sciences, Vol.22, No.2, (February 1997), pp. 37-38, ISSN 0968-0004

Martinez, F.; Chávez, E. \& Echegoyen, S. (1987). Decreased Exchange of Adenine Nucleotides in Human Placental Mitochondria. International Journal of Biochemistry, Vol.19, No.3, pp. 275-279, ISSN 1357-2725

Martinez, F.; Espinosa-García, M.T.; Flores-Herrera, O. \& Pardo, J.P. (1993). Respiratory Control Induced by ATP in Human Term Placental Mitochondria. Placenta, Vol.14, No.3, (May-June 1993), pp. 321-331. ISSN 0143-4004

Martinez, F.; Pardo, J.P.; Fores-Herrera. O. \& Espinosa-García, M.T. (1995). The Effect of Osmolarity on Human Placental Mitochondria Function. The International Journal of Biochemistry \& Cell Biology, Vol.27, No.8, (August 1995), pp. 795-803, ISSN 1357-2725

Martinez, F. \& Strauss J.F. III (1997). Regulation of Mitochondrial Cholesterol Metabolism. In: Subcellular Biochemistry: Cholesterol: its Functions and Metabolism in Biology and Medicine. Bittman, R., pp. 205-234, Plenum Press, ISBN 0306454785/0-306-45478-5, N.Y., USA.

Martinez, F.; Kiriakidou, M. \& Strauss J.F. III (1997). Structural and Functional Changes in Mitochondria Associated with Trophoblast Differentiation: Methods to Isolate Enriched Preparations of Syncytiotrophoblast Mitochondria. Endocrinology, Vol.138, No.5 (May 1997), pp. 2172-2183, ISSN 0013-7227 
Matalon, R. \& Michals, K. (1984). Gluconeogenic Enzymes in the Human Placenta. Journal of Inherited Metabolic Disease, Vol.7, No.4, (1984), pp. 179-181, ISSN 0141-8955

Matthews, H.R. (1995). Protein Kinases and Phosphatases that Act on Histidine, Lysine, or Arginine Residues in Eukaryotic Proteins: A Possible Regulator of the MitogenActivated Protein Kinase Cascade. Pharmacology \& Therapeutics, Vol.67, No.3, pp. 323-350, ISSN 0163-7258

Matsubara, S.; Takizawa, T. \& Sato, I. (1999). Glucose-6-Phosphatase is Present in Normal and Preeclamptic Placental Trophoblasts: Ultrastructural Enzyme-Histochemical Evidence. Placenta, Vol. 20, No.1, (January 1999), pp. 81-85, ISSN 0143-4004

Milan, R.; Flores-Herrera, O.; Espinosa-Garcia, M.T.; Olvera-Sanchez, S. \& Martinez, F. (2010). Contribution of Potassium in Human Placental Steroidogenesis. Placenta, Vol.31, No.10, (August-October 2010), pp. 860-866, ISSN 0143-4004

Miller, W.L. (2005). Minireview: Regulation of Steroidogenesis by Electron Transfer. Endocrinology, Vol.146, No.6, (June 2005), pp.2544-2550, ISSN 0013-7227

Meigs, R.A. \& Ryan, K.J. (1968). Cytochrome P-450 and Steroid Biosynthesis in the Human Placenta. Biochimica et Biophysica Acta, Vol.165, No.3, (October 1968), pp. 476-82, ISSN 0006-3002

Minauro-Sanmiguel, F.; Wilkens, S. \& Garcia, J.J. (2005). Structure of Dimeric Mitochondrial ATP Synthase: Novel F0 Bridging Features and the Structural Basis of Mitochondrial Cristae Biogenesis. Proceedings of the National Academy of Sciences, U.S.A., Vol.102, No.35, (August 2005), pp. 12356-12358, ISSN 1091-6490

Moe, A.J. (1995). Placental Amino Acid Transport. The American Journal of Physiology, Vol.268, No.6, Pt1, (June 1995), pp. C1321-C1331, ISSN 0002-9513

Moe, A.J.; Farmer, D.R.; Nelson, D.M. \& Smith, C.H. (1991). Pentose Phosphate Pathway in Cellular Trophoblast From Full-Term Human Placentas. The American Journal of Physiology, Vol.261, No.6Pt1, (December 1991), PP. C1042-1047, ISSN 0363-6127

Moog-Lutz, C.; Tomasetto, C.; Régnier, C.H.; Wendling, C.; Lutz, Y.; Muller, D.M.; Chenard, B.P. \& Rio, M. (1997). MLN64 Exhibits homology with the Steroidogenic Acute Regulatory Protein (StAR) and is Over-Expressed in Human Breast Carcinomas. International Journal of Cancer, Vol.71, No.2, (April 1997), pp. 183-191, ISSN 00207136

Munn, E.A. (1974). The Structure of Mitochondria, In: The cell, Saunders, W.B., pp. 414-419, Academic Press, ISBN 0-7216-3584-9, Germany.

Négrié, C.; Triadou, N.; Michel, O.; Bouhnik, J. \& Michel, R. (1979). Oxidative Phosphorylation Reactions and Cholesterol Hydroxylation Mechanisms in Human Term Placental Mitochondria. Journal of Steroid Biochemistry, Vol.11, No.2, (August 1979), pp. 1135-40, ISSN 0022-4731

Nestler, J.E. (1987). Modulation of Aromatase and P450 Cholesterol Side-Chain Cleavage Enzyme Activities of Human Placental Cytotrophoblasts by Insulin and InsulinLike Growth Factor I. Endocrinology, vol.121, No.5, (November 1987), pp. 1845-1852, ISSN 0013-7227

Nicastro, D.; Frangakis, A.S.; Typke, D. \& Baumeister, W. (2000). Cryo-Electron Tomography of Neurospora Mitochondria. Journal of Structural Biology, Vol.129, No.1, (February 2000), pp. 48-56, ISSN 1047-8477 
Olivera, A.A. \& Meigs, R.A. (1975). Mitochondria From human Term Placenta. I. Isolation and Assay Conditions for Oxidative Phosphorylation. Biochimica et Biophysica Acta, Bioenergetics, Vol.376, No.3, (March 1975), pp. 426-435, ISSN 0005-2728

Olvera-Sanchez, S.; Espinosa-Garcia, M.T.; Monreal, J.; Flores-Herrera, O. \& Martinez F. (2011). Mitochondrial Heat Shock Protein Participates in Placental Steroidogenesis. Placenta, Vol.32, No.3, (March-June 2011), pp. 222-229. ISSN 0143-4004

Palinski, W. (2009). Maternal- Fetal cholesterol transport in the placenta. Good, Bad and Target for Modulation. Circulation Research, Vol.104, No.5, (March 2009), pp. 569571, ISSN 0009-7330

Paumard, P.; Vaillier, J.; Coulary, B.; Schaeffer, J.; Soubannier, V.; Mueller, D.M.; Brethes, D.; di Rago, J.P. \& Velours, J. (2002). The ATP Synthase is Involved in Generating Mitochondrial Cristae Morphology. The EMBO Journal, Vol.21, No.3, (February 2002), pp. 221-230, ISSN 0261-4189

Payne, A.H. \& Hales, D.B. (2004). Overview of Steroidogenic Enzymes in the Pathway from Cholesterol to Active Steroid Hormones. Endocrine Reviews, Vol.25, No.6, (December 2004), pp. 947-970, ISSN 0163-769X

Pellegrini, L. \& Scorrano, L. (2007). A Cut Short to Death: Parl and Opa1 in the Regulation of Mitochondrial Morphology and Apoptosis. Cell Death \& Differentiation, Vol.14, No.4, (July 2007), pp. 1275-1284, ISSN 1350-9047

Pepe, G.J. \& Albretch, E.D. (1999). Regulation of Functional Differentiation of the Placental Villous Syncytiotrophoblast by Estrogen During Primate Pregnancy. Steroids, Vol.64, No.9, (September 1999), pp. 624-627 ISSN: 0039-128X

Perkins, G.A.; Renken, C.W.; Martone, M.E.; Young, S.J.; Ellisman, M. \& Frey, T. (1997). Electron Tomography of Neuronal Mitochondria: Three-Dimensional Structure and Organization of Cristae and Membrane Contacts. Journal of Structural Biology, Vol.119, No.3, (August 1997), pp. 260-272, ISSN 1047-8477

Perkins, G.A.; Song, J.Y.; Tarsa, L.; Deerinck, T.J.; Ellisman, M.H. \& Frey, T.G. (1998). Electron Tomography of Mitochondria from Brown Adipocytes Reveals Crista Junctions. Journal of Bioenergetics and Biomembranes, Vol.30, No.5, (October 1998), pp. 431-442, ISSN 0145-479X

Perkins, G.A; Renken, C.W.; Frey, T.G. \& Ellisman, M.H. (2001a). Membrane Architecture of Mitochondria in Neurons of the Central Nervous System. Journal of neuroscience research, Vol.66, No.5, (December 2001), pp. 857-865, ISSN 0360-4012

Perkins, G.A.; Renken, C.W.; van der Klei, I.J.; Ellisman, M.H. \& Neupert, W. (2001b). Electron Tomography of Mitochondria After the Arrest of Protein Import Associated with Tom19 Depletion. European Journal of Cell Biology, Vol.80, No.2, (February 2001), pp. 139-150, ISSN 0171-9335

Perkins, G.A.; Ellisman, M.H. \& Fox, D.A. (2003). Three-Dimensional Analysis of Mouse Rod and Cone Mitochondrial Cristae Architecture: Bioenergetic and Functional Implications. Molecular Vision, Vol.9, (March 2003), pp. 60-73, ISSN 1090-0535

Piquard, F.; Schaefer, A.; Dellenbach, P. \& Haberey, P. (1990). Lactate Movements in the Human Placenta In Situ. Biology of the Neonate, Vol.58, No.2, pp. 61-68, ISSN 00063126

Prendergast, C.H.; Parker, K.H.; Gray, R.; Venkatesan, S.; Bannister, P.; Castro-Soares, J.; Murphy, K.W.; Beard, R.W.; Regan, L.; Robinson, S.; Steer, P.; Halliday, D. \& 
Johnston, D.G. (1999). Glucose Production by the Human Placenta In Vivo. Placenta, Vol.20, No.7, (September 1999), pp. 591-598, ISSN 0143-4004

Prince, F.P. (2002). Lamellar and Tubular Associations of the Mitochondrial Cristae: Unique Forms of the Cristae Present in Steroid-Producing Cells. Mitochondrion, Vol.1, No.4, (February 2002), pp. 381-389, ISSN 1567-7249

Puttick, J.; Baker, E.N. \& Delbaere, L.T. (2008). Histidine Phosphorylation in Biological Systems. Biochimica et Biophysica Acta, Proteins and Proteomics, Vol.1784, No.1, (January 2008), pp. 100-105, ISSN 1570-9639

Reichert, A.S. \& Neupert, W. (2002). Contact Sites Between the Outer and Inner Membrane of Mitochondria-Role in Protein Transport, Biophysica Acta Molecular Cell Research, Vol.1592, No.1, (September 2002), pp. 41-49, ISSN 0167-4889

Ringler, G.E.; Kao, L.C.; Miller, W.L. \& Strauss, J.F. III (1989). Effects of 8-Bromo-cAMP on Expression of Endocrine Functions by Cultured Human Trophoblast cells. Regulation of Specific mRNAs. Molecular and Cellular Endocrinology, Vol.61, No.1, (Jan 1989), pp. 13-21, ISSN 0303-7207.

Ritvos, O. (1988). Modulation of Steroidogenesis in Choriocarcinoma Cells by Cholera Toxin, Phorbol Ester, Epidermal Growth Factor and Insulin-Like Growth Factor I. Molecular and Cellular Endocrinology, Vol.59, No.1-2, (September 1988), pp. 125-133, ISSN 0303-7207

Rossignol, R.; Gilkerson, R.; Aggeler R.; Yamagata, K.; Remington, S.J. \& Capaldi, R.A. (2004). Energy Substrate Modulates Mitochondrial Structure and Oxidative Capacity in Cancer Cells. American Association for Cancer Research, vol.64, (February 2004), No.3, pp. 985-893, ISSN 0008-5472

Sands, W. \& Palmer, T.M. (2008). Regulating Gene Transcription in Response to Cyclic AMP Elevation. Cellular Signaling, Vol.20 No.3, (March 2008), pp.460-466, ISSN 0898-6568

Schimmer, B.P. \& White, P.C. (2010). Steroidogenic Factor 1: Its Roles in Differentiation, Development, and Disease. Molecular Endocrinology, Vol.24, No.7, (July 2010), pp. 1322-1337, ISSN 0888-8809

Schneider, H.; Malek, A.; Duft, R. \& Bersinger, N. (1988). Evaluation of an In Vitro Dual Perfusion System for the Study of Placental Proteins: Energy Metabolism. In: Placenta as a model and a source, Genbacev, O.; Klopper, A. \& Beaconsfield. R., pp. 39-50, Plenum Press, ISBN 0306432382, New York, USA

Schägger, H. \& Pfeiffer, K. (2000). Supercomplexes in the Respiratory Chains of Yeast and Mammalian Mitochondria. The EMBO Journal, Vol.19, No.8, (April 2000), pp. 17771783, ISSN 0261-4189

Shelley, H.J. (1979). Transfer of Carbohydrates, In: Placental transfer, Chamberlain, G. \& Wilkinson, A.W. pp. 118-1412, Pitman Medical, ISBN 0272795313, Ithaca, New York, USA

Shi, C.Z. \& Zhuang, L.Z. (1993). Stimulatory Effect of Norepinephrine on Progesterone Production by Human First Trimester Placenta Explants In Vitro. Life Sciences, Vol.52, No.20, pp. 1657-65, ISSN 0024-3205

Simpson, E.R. \& Miller, D.A. (1978). Cholesterol Side-Chain Cleavage, Cytochrome P450, and Iron-Sulfur Protein in Human Placental Mitochondria. Molecular and Cellular Endocrinology, Vol.190, No.2, (October 1978), pp. 800-808, ISSN 0303-7207 
Spät, A. \& Pitter, J.G. (2004). The Effect of Cytoplasmic Ca2+ Signal on the Redox State of Mitochondrial Pyridine Nucleotides. Molecular and Cellular Endocrinology, Vol. 215, No.1-2, (February 2004), pp. 115-118, ISSN 0303-7207

Stocco, D.M. (2000). Intramitochondrial Cholesterol Transfer. Biochimica et Biophysica Acta, Molecular and Cell Biology of Lipids, Vol.1486, No.1, (June 2000), pp.184-197, ISSN 1388-1981

Stocco, D.M.; Wang, X.; Jo, Y. \& Manna, P.R. (2005). Multiple Signaling Pathways Regulating Steroidogenesis and Steroidogenic Acute Regulatory Protein Expression: More Complicated than we Thought. Molecular Endocrinology, Vol.19, No.11, (November 2005), pp.2647-2659, ISSN0888-8809

Strauss, J.F. III; Kido, S.; Sayegh, R.; Sakuragi, N. \& Gafvels, M.E. (1992). The cAMP Signalling System and Human Trophoblast Function. Placenta, Vol.13, No.5, (September-October 1992), pp. 389-403, ISSN 0143-4004

Strauss, J.F. III; Martinez, F. \& Kiriakidou, M. (1996). Placental Steroid Hormone Synthesis: Unique Features and Unanswered Questions. Biology of Reproduction, Vol.54, No.2, (February 1996), pp. 303-311, ISSN 0006-3363

Strauss, M.; Hofhaus, G.; Schröder, R.R. \& Kühlbrandt, W. (2008). Dimer Ribbons of ATP Synthase Shape the Inner Mitochondrial Membrane. The EMBO Journal, Vol.27, No.7, (April 2008), pp. 1154-1160, ISSN 0261-4189

Strushkevicha, N.; MacKenziea, F.; Cherkesovab, T.; Grabovecb, I.; Usanovb, S. \& Parka, H.W. (2011). Structural Basis for Pregnenolone Biosynthesis by the Mitochondrial Monooxygenase System. Proceedings of the National Academy of Sciences, USA. Vol.108, No.25, (June 2011), pp. 10139-10143 ISSN 0027-8424

Stulc, J.; Stulcová, B. \& Sibley, C.P. (1995). Mechanisms of the Fetomaternal Transfer of $\mathrm{Na}^{+}$ Across the Dually Perfused Placentaof the Rat. Placenta, Vol.16, No.2, (March 1995), pp. 127-135, ISSN 0143-4004

Stulc, J. (1997). Placental Transfer of Inorganic Ions and Water. Physiological Reviews, Vol.77, No.3, (July 1997), pp. 805-836, ISNN 0031-9333

Thomson, M. (2002). Evidence of Undiscovered Cell Regulatory Mechanisms: Phosphoproteins and Protein Kinases in Mitochondria. Cellular and Molecular Life Sciences, Vol.59, No.2, (February 2002), pp. 213-219, ISSN: 1420-682X

Trost, M.; Bridon, G.; Desjardins, M. \& Thibault, P. (2010). Subcellular Phosphoproteomics, In: Mass Spectrometry Reviews, Vol.29, No.6, (November-December 2010), pp. 962 990 ISNN 1098-2787

Tuckey, R.C. (1992). Cholesterol Side-Chain Cleavage by Mitochondria from the Human Placenta. Studies Using Hydroxycholesterols as Substrates. Journal of Steroid Biochemistry and Molecular Biology, Vol.42, No.8, (September 1992), pp. 883-890, ISSN 0960-0760

Tuckey, R.C. \& Headlam, M.J. (2002). Placental Cytochrome P450scc (CYP11A1): Comparison of Catalytic Properties Between Conditions of Limiting and Saturating Adrenodoxin Reductase. The Journal of Steroid Biochemistry and Molecular Biology, Vol.81, No.2, (June 2002), pp. 153-158, ISSN 0960-0760

Tuckey, R. C. (2005). Progesterone Synthesis by the Human Placenta, Placenta, Vol.26, No.4, (April 2005), pp. 273-281. ISSN 0143-4004

Uribe, A.; Flores-Herrera, O.; Rendón, J.L.; Espinosa-García, M.T. \& Martinez, F. (1999). Presence of Two Enzymes, Different from the $\mathrm{F}_{1} \mathrm{~F}_{0}$-ATPase, Hydrolyzing 
Nucleotides in Human Term Placental Mitochondria. The International Journal of Biochemistry \& Cell Biology, Vol.31, No.2, (February 1999), pp. 319-330. 1357-2725

Uribe, A.; Strauss J.F. III \& Martinez, F. (2003). Contact Sites from Human Placental Mitochondria. Characterization and Role in Progesterone Synthesis. Archives of Biochemistry and Biophysics, Vol.413, No.2, (May 2003), pp. 172-181, ISSN 0003-9861

Ville, C.A. (1953). The Metabolism of Human Placenta In Vitro. The Journal of Biological Chemistry, Vol.205, No.1, (November 1953), pp. 113-123, ISSN 0021-9258

Wollet, L. (2005). Maternal Cholesterol in Fetal Development: Transport of Cholesterol from Maternal to the Fetal Circulation. The American journal of clinical nutrition, Vol.82, No.6, (December 2005), pp. 1155-1161, ISSN 0002-9165

Xu, X.; Xu, T.; Robertson, D.G \& Lamberth, J.D. (1989). GTP Stimulates Pregnenolone Generation in Isolated Rat Adrenal Mitochondria. Journal of Molecular Biology, Vol.264, No.30, (October 1989), pp. 17674-17680, ISSN 0022-2836

Young, M.P. \& Schneider, H. (1984). Metabolic Integrity of the Isolated Perfused Lobule of Human Placenta. Placenta, Vol.5, No.2, (March-April 1984), pp. 95-104. ISSN 01434004

Yudilevich D.L. \& Sweiry J.H. (1985). Transport of Amino Acids in the Placenta. Biochemica et Biophys Acta, Vol.822, No.2, (September 1985), pp. 169-201, ISSN 0006-3002

Zosmer, A.; Elder, M.G. \& Sullivan, M.F. (1997). Second Messenger and the Control of Progesterone Production from First Trimester Trophoblast. The Journal of Steroid Biochemistry and Molecular Biology, Vol.62, No.2-3, (June 1997), pp. 201-205, ISSN 0960-0760 


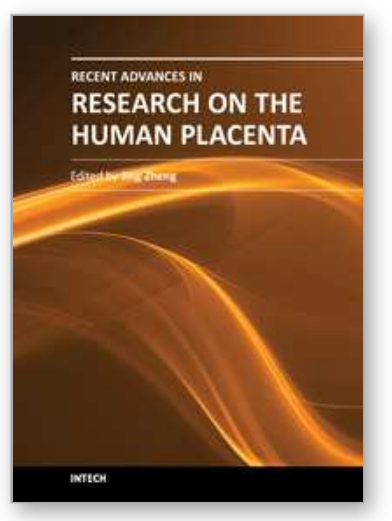

\author{
Recent Advances in Research on the Human Placenta \\ Edited by Dr. Jing Zheng
}

ISBN 978-953-51-0194-9

Hard cover, 428 pages

Publisher InTech

Published online 07, March, 2012

Published in print edition March, 2012

This book contains the total of 19 chapters, each of which is written by one or several experts in the corresponding field. The objective of this book is to provide a comprehensive and most updated overview of the human placenta, including current advances and future directions in the early detection, recognition, and management of placental abnormalities as well as the most common placental structure and functions, abnormalities, toxicology, infections, and pathologies. It also includes a highly controversial topic, therapeutic applications of the human placenta. A collection of articles presented by active investigators provides a clear update in the area of placental research for medical students, nurse practitioners, practicing clinicians, and biomedical researchers in the fields of obstetrics, pediatrics, family practice, genetics, and others who may be interested in human placentas.

\title{
How to reference
}

In order to correctly reference this scholarly work, feel free to copy and paste the following:

Federico Martinez, Rebeca Milan, Oscar Flores-Herrera, Sofia Olvera-Sanchez, Erika Gomez-Chang and Maria Teresa Espinosa-Garcia (2012). The Role of Mitochondria in Syncytiotrophoblast Cells: Bioenergetics and Steroidogenesis, Recent Advances in Research on the Human Placenta, Dr. Jing Zheng (Ed.), ISBN: 978953-51-0194-9, InTech, Available from: http://www.intechopen.com/books/recent-advances-in-research-onthe-human-placenta/the-role-of-mitochondria-in-syncytiotrophoblast-cells-bioenergetics-and-steroidogenesis

\section{INTECH}

open science | open minds

\section{InTech Europe}

University Campus STeP Ri

Slavka Krautzeka 83/A

51000 Rijeka, Croatia

Phone: +385 (51) 770447

Fax: +385 (51) 686166

www.intechopen.com

\section{InTech China}

Unit 405, Office Block, Hotel Equatorial Shanghai

No.65, Yan An Road (West), Shanghai, 200040, China

中国上海市延安西路65号上海国际贵都大饭店办公楼 405 单元

Phone: +86-21-62489820

Fax: $+86-21-62489821$ 
(C) 2012 The Author(s). Licensee IntechOpen. This is an open access article distributed under the terms of the Creative Commons Attribution 3.0 License, which permits unrestricted use, distribution, and reproduction in any medium, provided the original work is properly cited. 